\title{
Contributions of Professor M. Kabir Hassan to the Islamic Finance Literature: A Bibliometric Study
}

\author{
(Sumbangan Profesor M. Kabir Hassan terhadap Literatur Kewangan Islam: Suatu Kajian \\ Bibliometrik)
}

\author{
Mohammad Mushfiqul Haque Mukit \\ Jahangirnagar University
}

Aishath Muneeza

International Centre for Education in Islamic Finance (INCEIF)

Andrea Paltrinieri

Università Cattolica del Sacro Cuore

ABSTRACT

This study presents Professor M. Kabir Hassan's productivity, citations, collaborations with fellow researchers, publications, and content analysis with future research direction in conjunction with his $30^{\text {th }}$ academic anniversary which is marked in 2021. The bibliometric and thematic analysis of the scientific legacy of Professor M. Kabir Hassan was conducted based on his publications from 1991 to 2021. During his long career, he has published 346 journal articles with 23,059 citations and collaborated with 292 authors globally. The findings of conceptual and empirical research papers published by Professor M. Kabir Hassan are crucial for the theoretical developments of Islamic finance, as well as its practical developments as a distinctive discipline. We have derived several research areas for future research based on the research works published by Professor M. Kabir Hassan, as follows: i) the issue of Islamic common market that needs to be examined further in the light of new data and changing global perspectives; ii) a study on the issues faced by Islamic banks in adopting Basel III and capital adequacy framework for Islamic banks; iii) new models for takaful need to be explored; iv) the cost of faith-based investing needs to be studied in the recent times, especially to understand the impact of the pandemic on it; v) a study to understand the perception of the government of Bangladesh, and international and multilateral organisations on the role of zakat to alleviate poverty; vi) the level of technology adoption by Islamic banks can be studied; and vii) the successful implementation of equity-based Islamic finance contracts could be empirically studied.. It is anticipated that this research will motivate young and emerging scholars, as well as existing scholars, to excel in their arenas by producing quality research and publications in a consistent manner.

Keywords: Citations; financial industry; growth; Islamic finance; productivity; socioeconomic. JEL: C80, G00, M20, A39, Y9, Z0.

ABSTRAK

Kajian ini menunjukkan produktiviti, sitasi, kolaborasi dengan rakan penyelidik, penerbitan, dan analisis kandungan Profesor M. Kabir Hassan dengan arah penyelidikan masa depan sempena ulang tahun akademiknya yang ke-30 pada tahun 2021. Analisis bibliometrik dan tematik mengenai warisan ilmiah Profesor M. Kabir Hassan dilakukan berdasarkan penerbitannya dari tahun 1991 hingga 2021. Selama kariernya yang panjang, beliau telah menerbitkan 346 artikel jurnal dengan 23,059 sitasi dan berkolaborasi dengan 292 pengarang di seluruh dunia. Penemuan makalah penyelidikan konseptual dan empirikal yang diterbitkan oleh Profesor M. Kabir Hassan sangat berguna untuk perkembangan teori kewangan Islam, dan juga perkembangan praktikalnya sebagai disiplin khas. Kami telah mendapat beberapa bidang kajian untuk penyelidikan masa hadapan berdasarkan karya penyelidikan yang diterbitkan oleh Profesor M. Kabir Hassan, seperti berikut: i) isu pasaran awam Islam yang perlu diteliti lebih lanjut dengan mempertimbangkan data baru dan perubahan perspektif global; ii) kajian mengenai isu-isu yang dihadapi oleh bank Islam dalam menerapkan Basel III dan kerangka kerja kecukupan modal untuk bank Islam; iii) model baharu untuk takaful perlu diterokai; iv) kos pelaburan berasaskan kepercayaan perlu dikaji pada tahun semasa, terutama untuk memahami kesan wabak ke atasnya; v) kajian untuk memahami persepsi pemerintah Bangladesh, dan organisasi antarabangsa dan multilateral mengenai peranan zakat untuk mengurangkan kemiskinan; vi) tahap penggunaan teknologi oleh bank Islam dapat dikaji; dan vii) keberhasilan pelaksanaan kontrak kewangan Islam berasaskan ekuiti dapat dikaji secara empirik. Dijangkakan bahawa penyelidikan ini akan memotivasi para sarjana muda dan yang

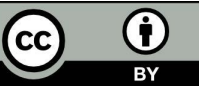

This article is published under the Creative Commons Attribution 4.0 International (CC BY 4.0) license. 
baru muncul, serta para sarjana sedia ada, untuk berjaya dalam bidang mereka dengan menghasilkan penyelidikan dan penerbitan yang berkualiti secara konsisten.

Kata kunci: Sitasi; industry kewangan; pertumbuhan; kewangan Islam; produktiviti; sosioekonomi.

Received 20 July 2021; Revised 24 August 2021; Accepted 26 August 2021; Available online 3 September 2021

\section{INTRODUCTION}

The biographies of scholars are considered as an important branch of social science history because they point to the scientific actor standing behind the development of theories and practices (Garraty 1957; Ileto 2014; Samuelson 2007). Khalid and Ur-Rehman (2009) stated that bio-bibliometrics is the biographical study of the individual author. Bibliometric analysis of publications uses quantitative and analytical methods to ascertain and establish functional relationships between elements in bio-data and biblio-data. Bio-bibliometrics is different from the study of scientometrics, which focuses only on scientists and not on academicians or researchers from the arts, humanities, and social science fields (Khalid \& Ur-Rehman 2009; Sin 1999). Unlike other old fields of study, the Islamic finance field has moderate academic contributions at this point of literature (Al Rahahleh et al. 2019; Alamad 2017; Lone \& Ahmad 2017) given the brief history of the knowledgebase. In this regard, Professor M. Kabir Hassan from the Department of Economics and Finance at the University of New Orleans (UNO) is considered as one of the forefront researchers, academics, and subject specialists in Islamic finance by many contemporary scholars. Professor M. Kabir Hassan, the world's indisputable leader in Islamic finance, has been offering the highest level of service with his wisdom and talents. He is the winner of the 2016 Islamic Development Bank (IsDB) Prize in Islamic Banking and Finance (Soong 2019). He currently holds three endowed chairs, namely, as the Hibernia Professor of Economics and Finance, the Hancock Whitney Chair Professor in Business, and the Bank One Professor in Business at the University of New Orleans. At this point of his long scholarly career, he has established himself as one of the strongest academic editors in the field of Islamic finance. A list of journals previously edited by Professor M. Kabir Hassan is shown in Table 1.

Table 1 clearly demonstrates the impact he has on academic research leadership in different editorial roles. Under his guidance, the International Journal of Islamic and Middle Eastern Finance and Management under Emerald Publishing has grown to be the most prestigious Islamic finance journal in the world. Various international regulatory bodies have routinely published their findings and policy papers through this medium. His work on Islamic finance has also given him the position of a subject specialist editor in some of the most prominent mainstream finance journals, including the International Journal of Emerging Markets, the Review of International Business and Finance, the International Review of Economics and Finance, and the PacificBasin Finance Journal.

TABLE 1. Contribution - Editorial activities

\begin{tabular}{|c|c|c|c|c|}
\hline No & Journal & Indexation & Editorship Position & Publisher \\
\hline 1 & $\begin{array}{l}\text { Journal of Islamic And Middle Eastern Finance } \\
\text { and Management }\end{array}$ & Scopus, ABDC, ABS And SSCI & Editor-In-Chief & Emerald \\
\hline 2 & International Journal of Emerging Markets & Scopus, ABDC, ABS And SSCI & Senior Editor & Emerald \\
\hline 3 & Review of International Business and Finance & Scopus, ABDC, ABS And ESCI & Associate Editor & Elsevier \\
\hline 4 & International Review of Economics and Finance & Scopus, ABDC, ABS And ESCI & Associate Editor & Elsevier \\
\hline 5 & Pacific-Basin Finance Journal & Scopus, ABDC, ABS And ESCI & Associate Editor & Elsevier \\
\hline 6 & Thunderbird International Business Review & Scopus, ABDC, ABS And ESCI & Guest Editor & Wiley \\
\hline 7 & International Journal of Business and Society & Scopus, ABDC, ABS And ESCI & Guest Editor & $\begin{array}{l}\text { University } \\
\text { Malaysia } \\
\text { Sarawak }\end{array}$ \\
\hline 8 & Review of Financial Economics & Scopus, ABDC, ABS And ESCI & Guest Editor & Wiley \\
\hline 9 & Quarterly Review of Economics and Finance & Scopus, ABDC, ABS And ESCI & Guest Editor & Elsevier \\
\hline 10 & Singapore Economic Review & Scopus, ABDC, ABS And ESCI & Guest Editor & $\begin{array}{l}\text { World- } \\
\text { Scientific }\end{array}$ \\
\hline 11 & Annals of Operations Research & Scopus, ABDC, ABS And ESCI & Guest Editor & Springer \\
\hline
\end{tabular}

Source: Author Adopted (Data Processed, July 2021, all inclusive) 
His contribution includes guest-editing the Islamic Finance special issue in other multidisciplinary journals, such as the Thunderbird International Business Review, the International Journal of Business and Society, the Review of Financial Economics, the Quarterly Review of Economics and Finance, the Singapore Economic Review, and the Annals of Operations Research. Based on the previous table, true implications of his editorial leadership can be seen in two ways: i) all of his edited journals have been indexed in major indexes, and ii) he has covered all the big publishers in his career, including Emerald, Elsevier, Wiley, and Springer. These global academic presences and his impactful research have motivated us to write about his life contributions and services for this branch of knowledge. Readers will find this paper insightful because it is based on his seminal works. In this paper, we used a semibibliometric approach to analyse Professor M. Kabir Hassan's seminal scientific works to acknowledge his contribution to the Islamic finance audience. This paper is divided into seven sections. This first section presents the introduction, and then discussed the research objectives and research questions. Section two of this paper presents the biography of Professor M. Kabir Hassan, while section three discusses his seminal works, followed by section four that discusses the methodology used in this study. Section five presents the results and discussion, while section six presents the highlights of Professor M. Kabir Hassan's contribution to Islamic finance. The final section presents recommendations and conclusion.

\section{RESEARCH OBJECTIVES AND RESEARCH QUESTIONS}

The purpose of this study was to present a more detailed bio-bibliometric analysis of the rise of Professor M. Kabir Hassan, with literature in WoS indexed, Google Scholar, and Dimensions indexed journals spanning 30 years from 1991 to 2021 . This recent study is unique and up-to-date because it comprises of new and valuable data. The significant period of coverage of his work is from 1991 forward, within the time span covered by this paper. The findings in this current study will benefit the Islamic finance industry by divulging crucial data regarding Professor M. Kabir Hassan that will aid and guide future research. This study aimed to address the following research questions:

$\mathrm{RQ}_{1}$ What are the emerging trends of scientific citation growth related to Professor M. Kabir Hassan in Islamic finance research from 1991-2021?

$\mathrm{RQ}_{2}$ Who are the most prolific authors in the field of Islamic finance?

$\mathrm{RQ}_{3}$ Which countries, authors, publications, journals, and organisations, in collaboration with Professor
M. Kabir Hassan, have made the most significant contributions?

$\mathrm{RQ}_{4}$ What is Professor M. Kabir Hassan's scientific citation network?

$\mathrm{RQ}_{5}$ Which paper written by Professor M. Kabir Hassan has received the most citations?

$\mathrm{RQ}_{6}$ What are the main findings of the research papers published on Islamic finance by Professor M. Kabir Hassan and what is the future research direction that can be derived from it?

\section{BIOGRAPHY OF PROFESSOR M. KABIR HASSAN}

Professor M. Kabir Hassan is a Bangladeshi-American who was born on 1 October, 1963 in Bangladesh. He received his early education in Bangladesh. Professor Hassan secured first position in his Secondary School Certificate (SSC, equivalent to British O level examination) and Higher Secondary Certificate (HSC, equivalent to A Level), where both exams are nationally administered. He moved to the United States in 1983 and completed his studies to receive a Bachelor of Economics and Mathematics from Gustavus Adolphus College in Minnesota. He was awarded a Master's degree in economics and a Doctor of Philosophy in Finance from the University of Nebraska-Lincoln in 1987 and 1990, respectively. After receiving his doctorate, Hassan joined the Department of Economics and Finance at the University of New Orleans, where he is still working at the time this paper was written. $\mathrm{He}$ also holds the position of Distinguished Visiting Professor at the Faculty of Economics and Management at the National University of Malaysia at the time this paper was written.

Professor M. Kabir Hassan is renowned for his excellent work, and he has been awarded the honorary position of Hancock Whitney Bank Professor of Economics, Bank One Professor in Business, and Hibernia Professor of Economics and Finance at the University of New Orleans. He was also awarded prestigious recognitions, such as the Islamic Development Bank (ADB) prize in 2016, and numerous UNO prizes, such as UNO advisor of the year in 2018. Professor M. Kabir Hassan has numerous teaching awards for his outstanding teaching from the University of New Orleans and other academic organisations. His teaching awards include Jamaica Executive Master of Business Administration (JEMBA) (2002, 2003, and 2009), US Executive Master of Business Administration (EMBA) (1999, 2000, 2003, 2007, and 2015), Executive Masters in Health Care Management (EMHCM) (2002, 2003, and 2015), Thompson-Reuters Outstanding Educator (2002, 2004, and 2006), UNO College of Business Administration Professor of the Year (2001), UNO Favoured Professor (1998), and the University of Nebraska-Lincoln Graduate Assistant Award (1990). Professor M. Kabir Hassan won 27 Teaching Awards 
from UNO, and from external academic and professional organisations. He had also received the Islamic Banking and Finance Excellence Award from COMSATS University Islamabad (CUI), Lahore, Pakistan in 2017, and three more awards in 2019, namely, the Gordon H. "Nick" Mueller International Leadership Medallion from the University of New Orleans, the University of Louisiana System Outstanding Faculty Member Award, and the UNO Library Book Prize Award. He is also a member of several international organisations, such as the Governance and Ethics Board, and the Education Board, both under the Accounting and Auditing Organization for Islamic Financial Institutions (AAOIFI). Professor M. Kabir Hassan is a distinguished fellow in several universities, such as the National University of Malaysia (UKM) and the International Islamic University Malaysia (IIUM), Qassim University in Saudi Arabia, and University of Indonesia in Jakarta. He has also served as a visiting scholar for the international monetary fund and a visiting professor in numerous universities around the world: UKM, IIUM, University of Nottingham Malaysia, and University of Malaya in Malaysia; Qassim University, King Saud University, and Ummul Qura University in Saudi Arabia; University of Indonesia in Jakarta, Indonesia; Lahore University of Sciences and Management in Pakistan; Massey University in New Zealand; American University of Beirut in Lebanon; North South University in Dhaka, Bangladesh; and Drexel University in Philadelphia, Pennsylvania, and University of Nebraska, Lincoln, Nebraska, the USA. In this regard, he has been interviewed by major news and media services worldwide about his works. He was interviewed on the "Business Asia" Program, CNN on Corruption in Emerging Markets. His research works have been featured in Reuters, The Economist, New Orleans City Business, The Advocate, The Bangladesh Observer, The Financial Express, The Bangladesh Times, The Daily Star, The Independent, The Daily Ittefaq, The JanKantha, The Daily Sangram, The City Business (New Orleans), The Tempo (the National Indonesian Daily), National Public Radio (NPR), the British Broadcasting Corporation (BBC), Voice of America (VOA), Bangladesh TVs (Channel I, NTV, RTV, Bangla Vision, ETV, ATN Bangla, TBN24, and FBTV), Smart Beta (a podcast on research in economics, finance, and management), CBS, Fox, NBC, etc.

Professor M. Kabir Hassan has offered his academic leadership to several organisations, which include becoming the Financial Markets and Institutions Program Committee Chair for the Southern Finance Association (2017) and the Eastern Finance Association (2017), Vice President for the Local Arrangement of the Eastern Finance Association Meeting (2015), President of the Southwest Finance Association (SWFA) Meetings (2015-2016), Vice President of SWFA Meetings (20142015), Treasurer of SWFA Meetings (2012-2014), Vice
President of AIB-USSW (2000), President of AIB-USSW (2002-2003), Chapter Chair of AIB-USSW (2003-2007; 2013-2014), President of the Southwestern Society of Economists (SSE) (2006-2007), Program Chair and President Elect of SSE (2005-2006), President of the Association for Economic and Development Studies on Bangladesh (AEDSB) (2005-2007), Vice President of AEDSB (2000), General Secretary of AEDSB (19971998), Assistant General Secretary of AEDSB (19931995; 1995-1997), and General Secretary of the Islamic Economics Research Bureau, Dhaka, Bangladesh (1998-1999; 2000-2001). He was also a member of the Board of Directors, Academy of Financial Services from 1996 to 1999. He is currently the Board member of the Southern Finance Association (SFA).

\section{SEMINAL WORKS}

Professor M. Kabir Hassan has published more than 200 research papers on Islamic banking and finance in topranked refereed academic journals. More than 30 of his current papers have been accepted, but not yet published and over 50 papers are currently in the publication review process. His foremost achievement is to convey the importance of Islamic finance to the mainstream academic journals in economics and finance. $\mathrm{He}$ is among the few prolific researchers and authors to have published research on Islamic economics and finance in top-ranked refereed conventional finance journals. This achievement has helped increase the legitimacy and visibility of Islamic finance, which in turn, helped Islamic finance attracts a large readership. The presence of Islamic banking and finance literature in mainstream journals is a positive indicator that existing and new research scholars will be more likely to be attracted to the prospects of Islamic finance, and its scholarly and practical importance. Furthermore, it is important to note that Professor M. Kabir Hassan has collaborated, co-edited, and co-authored with many researchers and academicians globally in relation to Islamic finance, including books, research papers, working papers, conference papers, workshops, and seminars. His collaborators include prominent and junior scholars of Islamic finance from more than 25 countries. This collaboration on a global scale provides ample opportunities for knowledge sharing and learning about recent trends in the field of Islamic finance. His generous support to junior researchers also provides them a platform to learn from his experiences, and helps them enhance their knowledge and research experiences. Professor M. Kabir Hassan is currently a mentor to many research scholars and associates in numerous countries. His leadership in this area is lauded for producing current and future scholars in Islamic finance. Notably, these research scholars and co-authors include both Muslims and non-Muslims. Consequently, he has also been preaching Islamic economic thoughts to 
conventional and non-Muslim scholars. The following Figure 1 summarises the achievements of Professor M. Kabir Hassan thus far.

Professor M. Kabir Hassan's research capabilities and expertise are not confined to any specific area of Islamic finance. His scholarly expertise includes an understanding at a strategic level of both conventional and Islamic corporations, financial markets, banking, economics, and finance. He has produced an extensive body of literature on basic and advanced issues highlighted by experts and practitioners. His approach has been towards critical assessment, identification of potential problems, and recommendation of reliable solutions to facilitate the true and ultimate objectives of Islamic finance. His research ventures are mainly focused on areas related to financial stability, Islamic microfinances, legal environment, capital market regulations, Zakat regulations, regional studies, poverty alleviation, operational efficiency and determinants of Islamic bank performance, mutual funds, venture capital, comparative studies, equity advocacy, Islamic corporate finance, and literature reviews related to Islamic economic finance, to list a few examples. Professor M.
Kabir Hassan would follow up on his research and keep a keen eye on theoretical and practical developments in Islamic finance. Therefore, he has reached the status of a prominent scholar, who is consistently able to tackle controversial issues, and define new areas and challenges related to Islamic finance. The diverse scale of his knowledge and research makes him a prime intellectual asset, inspiration, and a force to be revered as a knowledge hub for Islamic finance.

Professor M. Kabir Hassan has been working relentlessly to make the world believe in the practicality of Islamic economics, banking, and finance. Although he is a financial economist with immense wisdom in conventional economics and finance, he is mainly recognised as an Islamic finance scholar. Very few Islamic scholars have succeeded in presenting the concepts of Islamic finance in such a globally accepted manner. A Google search on "Kabir Hassan" will yield more than a million results, most of which are related to his works on Islamic finance and economics. On the right-hand side of the search page, Google presents him as an author of many books on Islamic finance published by world-renowned publishing companies. A summary

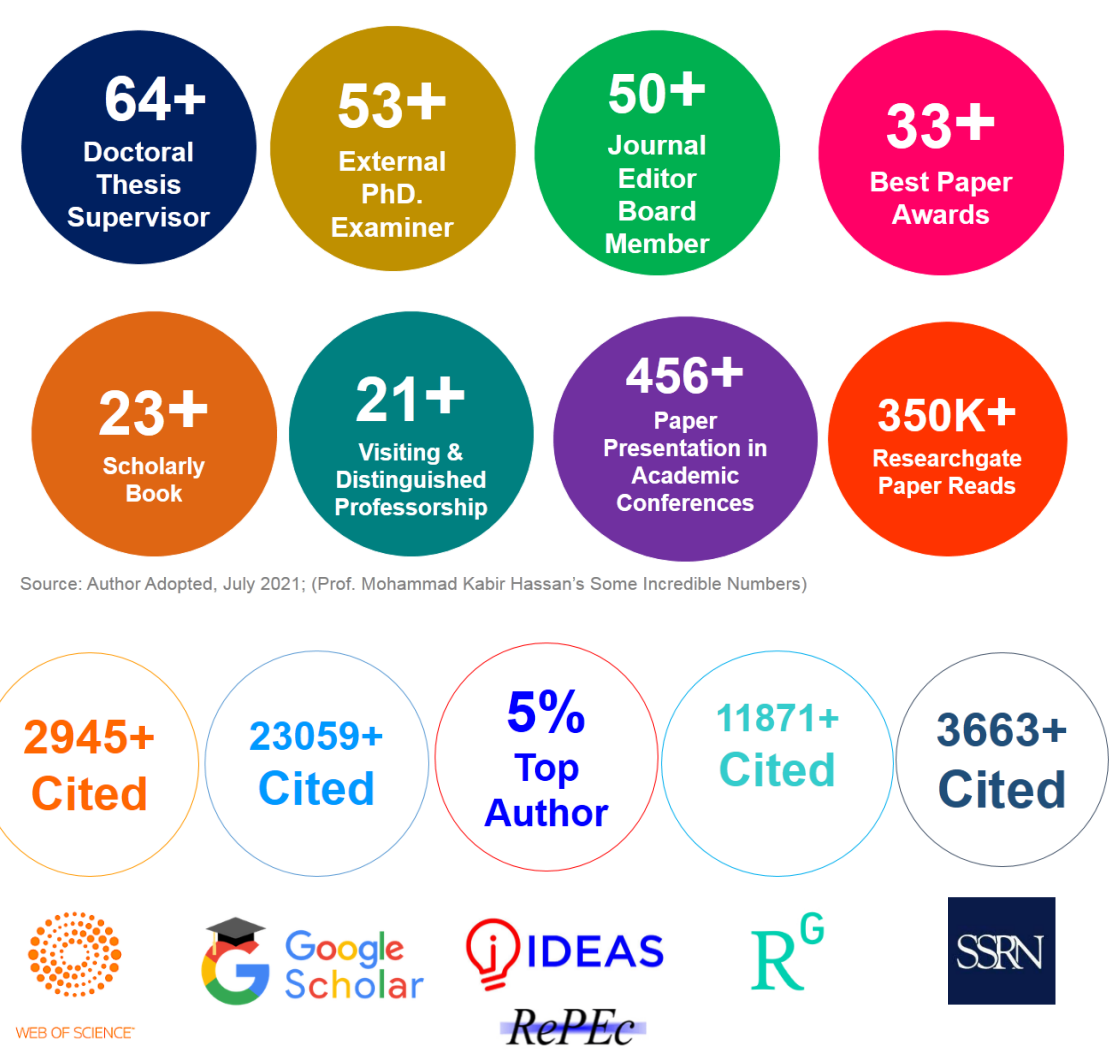

Source: Author Adopted, July 2021; (Prof. Mohammad Kabir Hassan's Some Incredible Numbers)

FIGURE 1. Professor M. Kabir Hassan's Lifelong Achievements 
of his research works from Google Scholar is presented in Table 2, followed by Figure 2 with his citation growth in the last 10 years.

In this paper, we have systematically selected his 96 top-cited seminal works, as presented in Table 3. The data presented in the table clearly suggest the depth of his work on Islamic finance and related knowledgebase. Most of his works are published in renowned journals, including the Journal of Banking and Finance, the Quarterly Review of Economics and Finance, the Journal of Corporate Finance, the Emerging Markets Review, the Pacific-Basin Finance Journal, the Economics Letters, the Finance Research Letters, the Journal of Financial Services Research, and the Research in International Business and Finance. Interestingly, his research strength is evenly divided between quantitative and qualitative methodologies. However, based on Table 1, he clearly prefers multi-

TABLE 2. Contribution - Google Scholar Data: This table presents the editorial activities of the author. The data for this analysis are collected from the Google Scholar website, as per the current academic standards

\begin{tabular}{|c|c|c|c|}
\hline As of $01 / 07 / 2021$ & All-time & Since 2016 & Remarks \\
\hline \multirow[t]{4}{*}{ Citation } & 23,059 & 13,812 & Top $1 \%$ among Islamic economists \\
\hline & & & $\begin{array}{l}\text { Among the top } 5 \% \text { of authors according to number of journal pages at RePEc/ } \\
\text { IDEAS }\end{array}$ \\
\hline & & & $\begin{array}{l}\text { - Among the top three presenters at the Financial Management Annual Meetings } \\
\text { since } 1990 \text { to } 2021\end{array}$ \\
\hline & & & - Won more than 20 Best Paper Awards from Academic Conference presentations \\
\hline \multirow[t]{3}{*}{ h-index } & 70 & 53 & h-index considers the number of papers written and their impact \\
\hline & & & - A $70 \mathrm{~h}$-index is exceptional and measures the impact of published articles \\
\hline & & & Among the top $1 \%$ of Islamic scholars with such a high h-index \\
\hline \multirow[t]{2}{*}{ i10-index } & 381 & 287 & Few authors in the field of finance have an i10-index of 374 or higher \\
\hline & & & Professor M. Kabir Hassan belongs to the top $1 \%$ of Islamic financial economists \\
\hline
\end{tabular}

Source: Author Adopted, Data Processed from Google Scholar (July 2021)

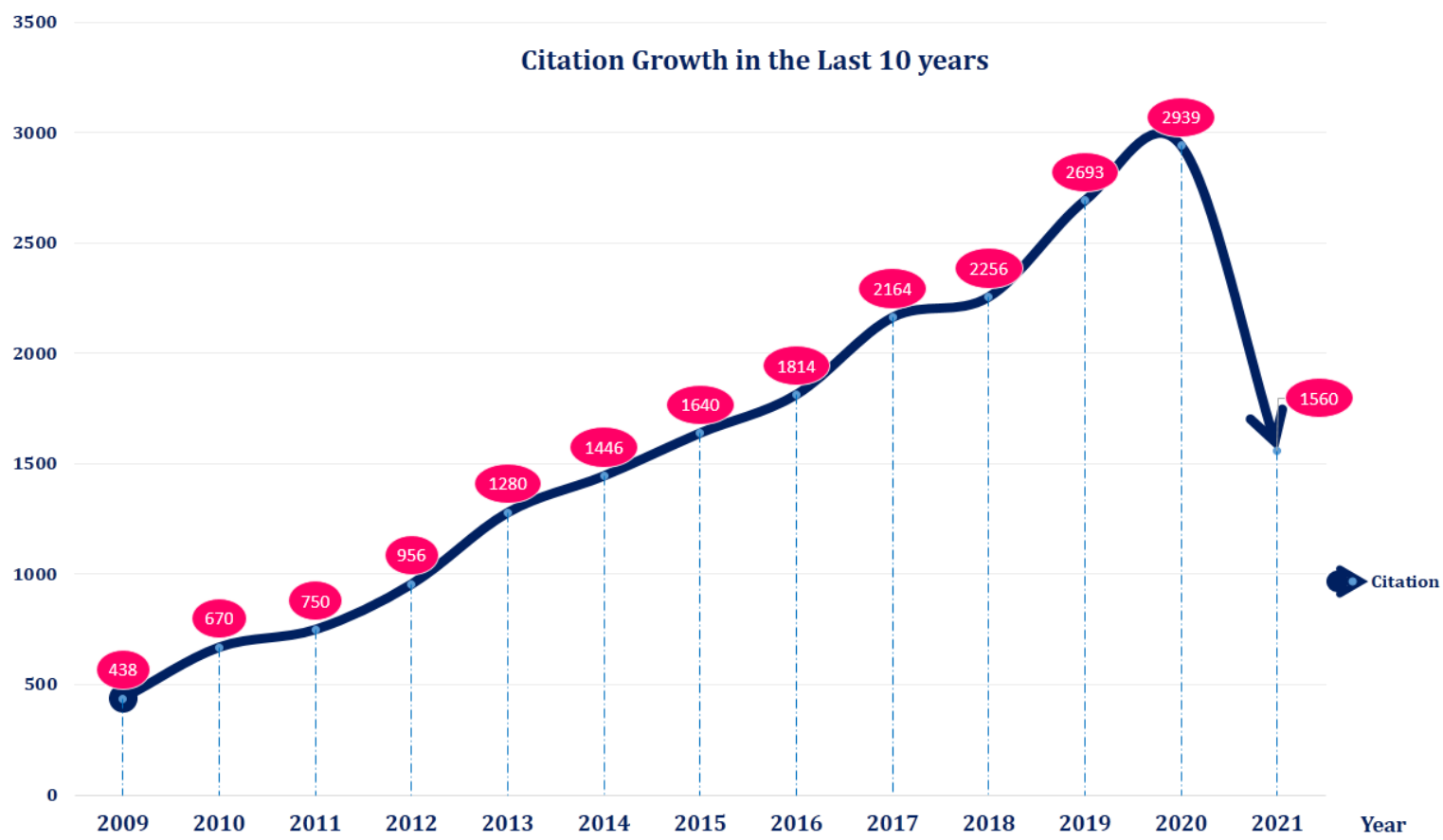

FIGURE 2. Contribution - Citation growth trends in the last 10 years

Source: Author Adopted, Data Processed (July 2021)

*This figure presents the citation growth for the author in the last 10 calendar years. The data for this analysis are collected from Google Scholar, as per the current academic standards. There are more than $400 \%$ increase in the number of citations for the author compared to the data from 10 years ago. 


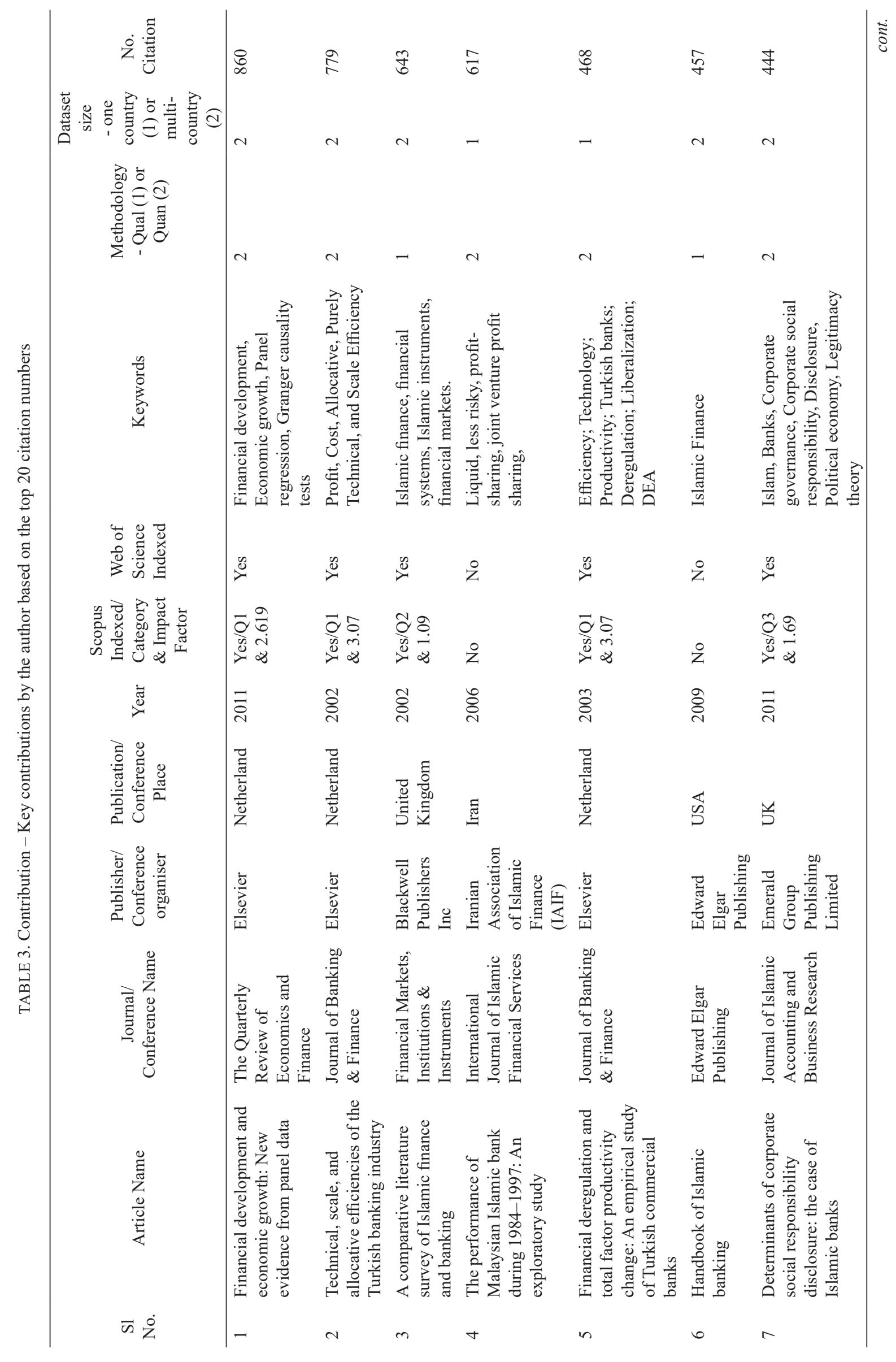




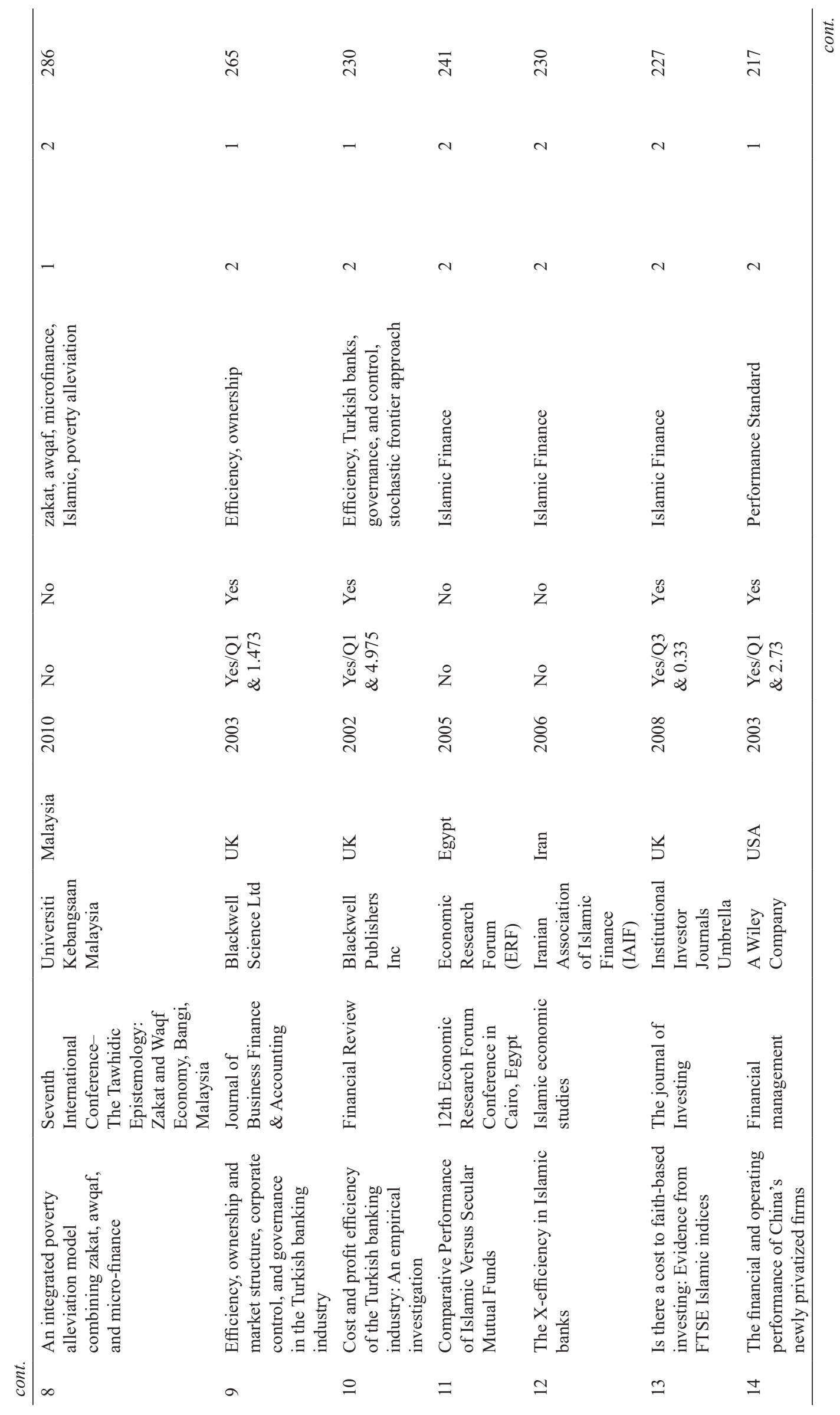




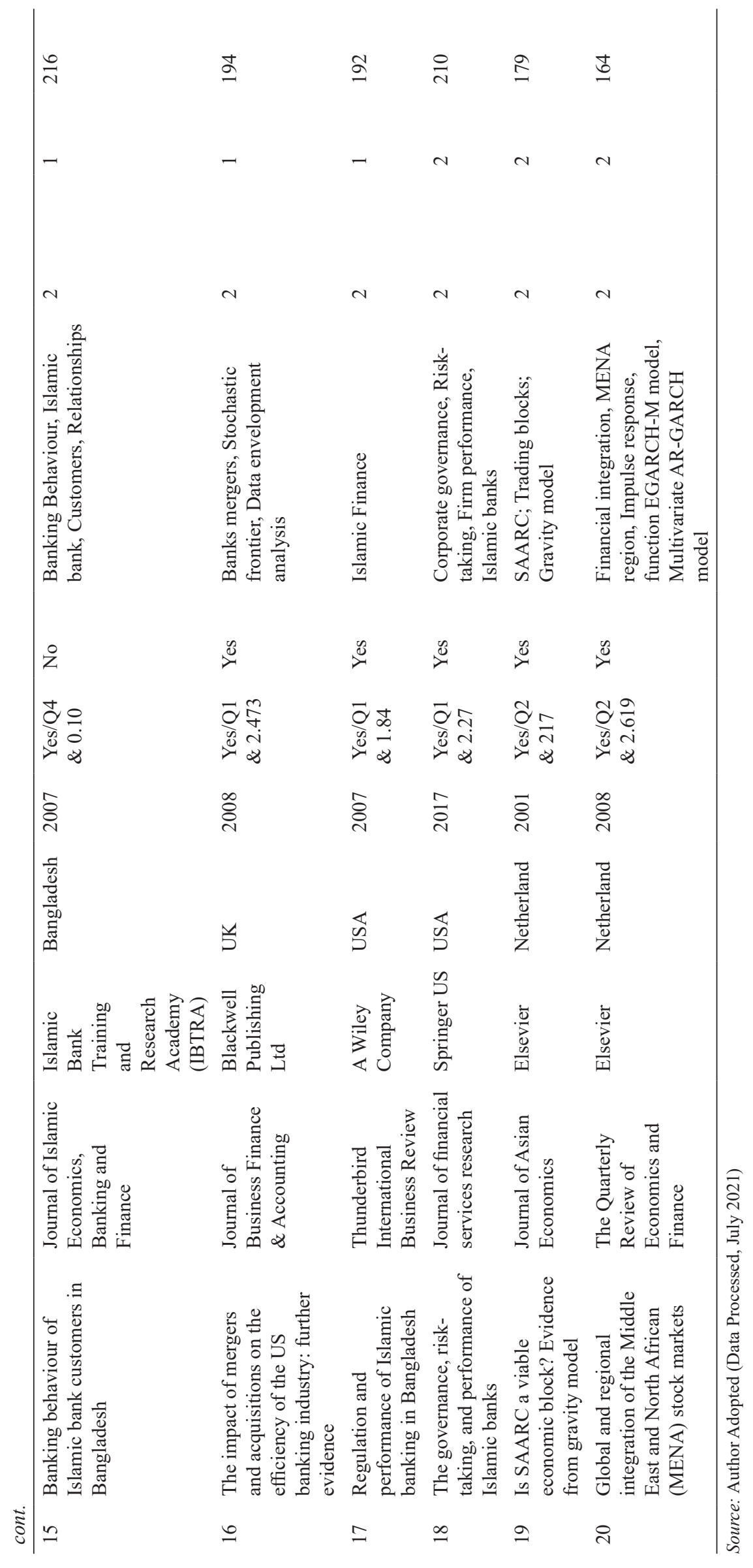


country studies over a single-country model, as well as journals published by the top four publishers, namely, Elsevier, Wiley, Springer, and Emerald. These data show a clear picture of his excellence in research. If we further breakdown his research based on which country his works are focused on, we will see approximately $40 \%$ of his works are based on the US. Our conclusion is cemented by the results shown in Figure 3, where Prof Kabir's word cloud for prominent work is Islamic Finance.

\section{METHODOLOGY}

When E. Wyndham Hulme gave two lectures as the Sandars Reader in Bibliography at the University of Cambridge in 1922, he appeared to have coined the phrase statistical bibliography. The lectures were later released as a book (Hulme 1923). Statistical bibliography can be utilised to apply quantitative approaches to determine the intellectual structure of any scientific topic (Hota et al. 2019). To conduct a retrospective analysis of Professor M. Kabir Hassan's seminal work in finance, we used a variety of tools, such as bibliographic coupling (Kessler 1963; Weinberg 1974), author keyword co-occurrence, and co-authorship analysis. Statistical bibliography also employs bibliometric indicators (Garfield 1955) to describe bibliographic data, such as the total number of journal publications and citations (Ding et al. 2017), which are used to assess productivity and influence (Svensson 2010). Citations per article and the h-index, for example, combine both journal publications and citations (Alonso et al. 2009; Hirsch 2005). In July 2021, a search of the WoS, Dimensions, and Scopus databases revealed 346 publications. All articles published after July 2021 were removed from this study because it marks his 30th anniversary of research contributions in the field of Islamic finance. A literature analysis was conducted using bibliometric tools, such as Bibexcel (Persson et al. 2009), Gephi, and VOSViewer (Van Eck \& Waltman 2010).

\section{RESULTS AND DISCUSSION}

\section{THE MOST PROLIFIC AUTHORS IN THE FIELD OF ISLAMIC FINANCE}

Professor M. Kabir Hassan is the most prolific author in Islamic finance with i10-index of 370 and 23,059 citations, followed by Dr. Muhammad Umar Chapra of the IsDB with i10-index of 90 and 9,927 citations, as shown in Table 4A. We report the results for IsDB laureates in Islamic economics, banking, and finance based on the number of citations for their work in Table 4A. For comparison purposes, we also show the citation

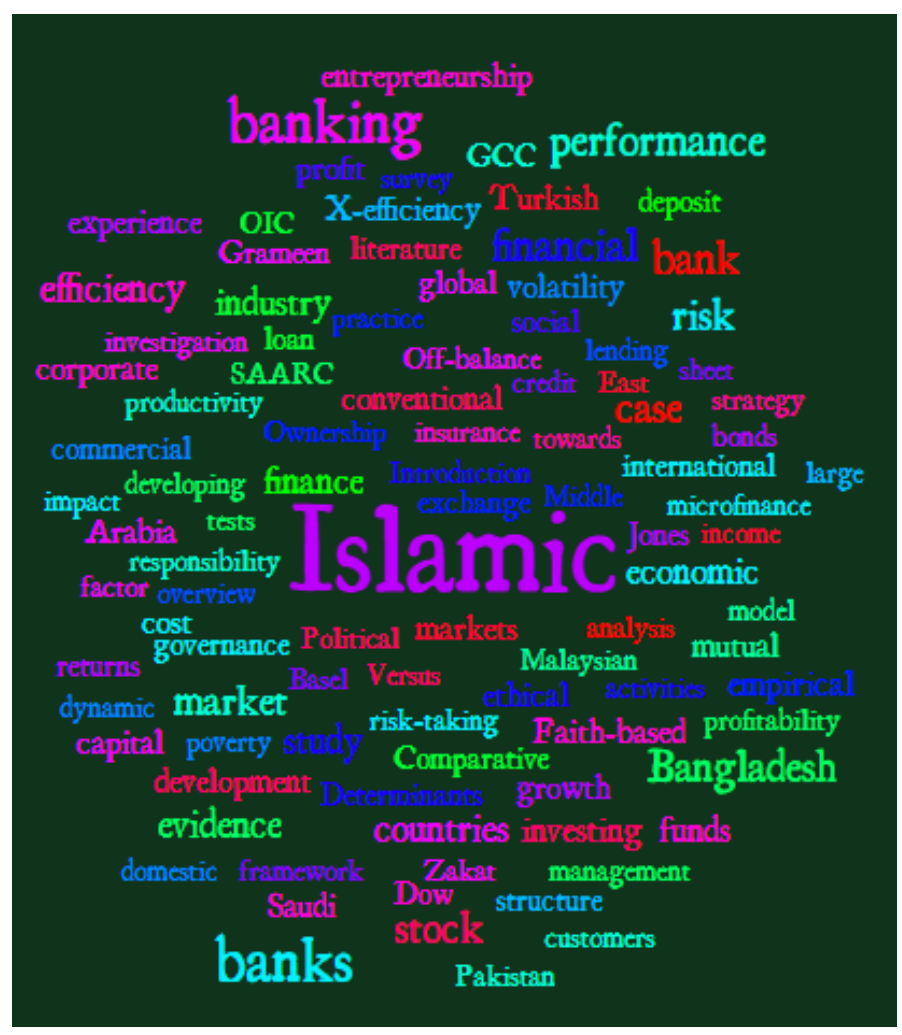

FIGURE 3. Contribution - Scope/field of cited work Source: Author Adopted 
TABLE 4A. The most prolific research scholars in Islamic Finance

\begin{tabular}{|c|c|c|c|c|c|}
\hline Author & Designation & University /Organization & $\begin{array}{l}\text { i10- } \\
\text { index }\end{array}$ & Citation & $\begin{array}{l}\text { The Islamic Development } \\
\text { Bank (IsDB) Award }\end{array}$ \\
\hline $\begin{array}{l}\text { Dr. Muhammad Umar } \\
\text { Chapra }\end{array}$ & Advisor & $\begin{array}{l}\text { The Islamic Development Bank } \\
\text { (IDB) Saudi Arabia }\end{array}$ & 90 & 9,927 & $\begin{array}{l}\text { Islamic Economics } \\
(1409 \mathrm{H} / 1989)\end{array}$ \\
\hline $\begin{array}{l}\text { Dr. Muhammad Anas } \\
\text { Zarqa }\end{array}$ & Senior Advisor & $\begin{array}{l}\text { Shura Sharia Consultancy } \\
\text { Kuwait }\end{array}$ & 8 & 1420 & $\begin{array}{l}\text { Islamic Economics } \\
(1410 \mathrm{H} / 1990)\end{array}$ \\
\hline Dr. Monzer Kahf & Professor & $\begin{array}{l}\text { Istanbul Sabahattin Zaim } \\
\text { University Turkey }\end{array}$ & 82 & 4,770 & $\begin{array}{l}\text { Islamic Economics } \\
(1421 \mathrm{H} / 2001)\end{array}$ \\
\hline Dr. Abbas Mirakhor & $\begin{array}{l}\text { Executive } \\
\text { Director and } \\
\text { the Dean of the } \\
\text { Board Institution }\end{array}$ & $\begin{array}{l}\text { International Monetary Fund } \\
\text { (IMF), USA }\end{array}$ & 98 & 7,649 & $\begin{array}{l}\text { Islamic Economics } \\
(1423 \mathrm{H} / 2003)\end{array}$ \\
\hline Dr. Mohsin Khan & Senior Fellow & $\begin{array}{l}\text { The Rafik Hariri Center for } \\
\text { the Middle East at the Atlantic } \\
\text { Council in Washington DC, } \\
\text { USA }\end{array}$ & 144 & 20,264 & $\begin{array}{l}\text { Islamic Economics } \\
(1423 \mathrm{H} / 2003)\end{array}$ \\
\hline Dr. Zubair Hasan & $\begin{array}{l}\text { Professor } \\
\text { Emeritus }\end{array}$ & $\begin{array}{l}\text { International Centre for } \\
\text { Education in Islamic Finance } \\
\text { (INCEIF) }\end{array}$ & 41 & 5,138 & $\begin{array}{l}\text { Islamic Economics } \\
(1430 \mathrm{H} / 2009)\end{array}$ \\
\hline $\begin{array}{l}\text { Dr. Mohammad Kabir } \\
\text { Hassan }\end{array}$ & Professor & $\begin{array}{l}\text { Chairs-Hibernia Professor } \\
\text { of Economics and Finance, } \\
\text { Hancock Whitney Chair } \\
\text { Professor in Business, and Bank } \\
\text { One Professor in Business, } \\
\text { University of New Orleans, } \\
\text { USA }\end{array}$ & 370 & 23,059 & $\begin{array}{l}\text { Islamic Banking and } \\
\text { Finance }(1437 \mathrm{H} / 2016)\end{array}$ \\
\hline Dr. Mabid Ali al-Jarhi & $\begin{array}{l}\text { Shariah Board } \\
\text { Member \& } \\
\text { Professor }\end{array}$ & $\begin{array}{l}\text { Dubai Financial Market \& } \\
\text { Social Sciences University of } \\
\text { Ankara (Ankara Sosyal Bilimler } \\
\text { Üniversitesi) }\end{array}$ & 19 & 620 & $\begin{array}{l}\text { Islamic Economics, } \\
\text { Banking and Finance } \\
(1440 \mathrm{H} / 2019)\end{array}$ \\
\hline $\begin{array}{l}\text { Dr. Abul Mansur M. } \\
\text { Masih }\end{array}$ & Senior Professor & $\begin{array}{l}\text { Universiti Kuala Lumpur } \\
\text { Business School, Malaysia }\end{array}$ & 109 & 8,651 & $\mathrm{x}$ \\
\hline $\begin{array}{l}\text { Dr. Mohamed Ariff } \\
\text { Syed Mohamed }\end{array}$ & Professor & Sunway University Malaysia & 132 & 7,489 & $\mathrm{x}$ \\
\hline
\end{tabular}

Source: Author Adopted

TABLE 4B. The Islamic Development Bank Institute (IsDB) Prize List of the Previous Laureates in Islamic Economics, Banking \& Finance

\begin{tabular}{|c|c|c|c|}
\hline Laureate & $\begin{array}{l}\text { Citizenship/ } \\
\text { Country }\end{array}$ & University / Organisation Affiliation & $\begin{array}{l}\text { The Branch of Islamic } \\
\text { Development Bank } \\
\text { (IsDB) Award \& Year }\end{array}$ \\
\hline Prof. Khurshid Ahmad & Pakistan & Professor, Karachi University & $\begin{array}{l}\text { Islamic Economics } \\
(1408 \mathrm{H} / 1988)\end{array}$ \\
\hline $\begin{array}{l}\text { Dr. Sami Hasan Ahmad } \\
\text { Homoud }\end{array}$ & Jordan & The Islamic Development Bank (IsDB) & $\begin{array}{l}\text { Islamic Banking and } \\
\text { Finance }(1409 \mathrm{H} / 1989)\end{array}$ \\
\hline $\begin{array}{l}\text { Dr. Muhammad Umar } \\
\text { Chapra }\end{array}$ & $\begin{array}{l}\text { Saudi } \\
\text { Arabia }\end{array}$ & The Islamic Development Bank (IsDB) & $\begin{array}{l}\text { Islamic Economics } \\
(1409 \mathrm{H} / 1989)\end{array}$ \\
\hline $\begin{array}{l}\text { Dr. Muhammad Anas } \\
\text { Zarqa }\end{array}$ & Syria & Senior Advisor, Shura Sharia Consultancy Kuwait & $\begin{array}{l}\text { Islamic Economics } \\
(1410 \mathrm{H} / 1990)\end{array}$ \\
\hline
\end{tabular}




\begin{tabular}{|c|c|c|c|}
\hline Dr. Ziauddin Ahmad & Pakistan & Advisor, Institute of Policy Studies & $\begin{array}{l}\text { Islamic Banking and } \\
\text { Finance }(1411 \mathrm{H} / 1991)\end{array}$ \\
\hline $\begin{array}{l}\text { Dr. Yousuf Abdullah Al- } \\
\text { Qaradawi }\end{array}$ & Egypt & Chairman of the International Union of Muslim Scholars & $\begin{array}{l}\text { Islamic Economics } \\
(1411 \mathrm{H} / 1991)\end{array}$ \\
\hline Dr. Sabahuddin Zaim & Turkey & Professor, Istanbul University & $\begin{array}{l}\text { Islamic Banking and } \\
\text { Finance }(1412 \mathrm{H} / 1992)\end{array}$ \\
\hline $\begin{array}{l}\text { Dr. Ahmad Mohammed } \\
\text { Ali }\end{array}$ & $\begin{array}{l}\text { Saudi } \\
\text { Arabia }\end{array}$ & President of the Islamic Development Bank (IsDB) & $\begin{array}{l}\text { Islamic Banking and } \\
\text { Finance }(1414 \mathrm{H} / 1994)\end{array}$ \\
\hline $\begin{array}{l}\text { Dr. Muhammad Omar } \\
\text { Zubair }\end{array}$ & $\begin{array}{l}\text { Saudi } \\
\text { Arabia }\end{array}$ & The Islamic Development Bank (IsDB) & $\begin{array}{l}\text { Islamic Economics } \\
(1415 \mathrm{H} / 1995)\end{array}$ \\
\hline $\begin{array}{l}\text { Cheikh Saleh Abdullah } \\
\text { Kamel }\end{array}$ & $\begin{array}{l}\text { Saudi } \\
\text { Arabia }\end{array}$ & $\begin{array}{l}\text { Deputy Chairman, The Accounting and Auditing } \\
\text { Organization for Islamic Financial Institutions (AAOIFI) }\end{array}$ & $\begin{array}{l}\text { Islamic Banking and } \\
\text { Finance }(1416 \mathrm{H} / 1996)\end{array}$ \\
\hline Dr. Abdul Rahman Yousri & Egypt & $\begin{array}{l}\text { The Director General of the Higher Institute of Islamic } \\
\text { Research and Economics in Islamabad, Pakistan. }\end{array}$ & $\begin{array}{l}\text { Islamic Economics } \\
(1417 \mathrm{H} / 1997)\end{array}$ \\
\hline Dr. Rafic Al-Misri & Syria & The Islamic Development Bank (IsDB) & $\begin{array}{l}\text { Islamic Economics } \\
(1417 \mathrm{H} / 1997)\end{array}$ \\
\hline Dr. Tanzilur Rahman & Pakistan & Chief Justice, Federal Shariah Court of Pakistan & $\begin{array}{l}\text { Islamic Banking and } \\
\text { Finance }(1418 \mathrm{H} / 1998)\end{array}$ \\
\hline $\begin{array}{l}\text { Sheikh Dr. Mohammed } \\
\text { Al Habib Ibn Al Khoja }\end{array}$ & Tunisia & The Islamic Development Bank (IsDB) & $\begin{array}{l}\text { Islamic Economics } \\
(1419 \mathrm{H} / 1999)\end{array}$ \\
\hline Dr. Monzer Kahf & USA & Istanbul Sabahattin Zaim University & $\begin{array}{l}\text { Islamic Economics } \\
(1421 \mathrm{H} / 2001)\end{array}$ \\
\hline $\begin{array}{l}\text { Dr. Syed Muhammad } \\
\text { Hasanuzzaman }\end{array}$ & Pakistan & The Islamic Development Bank (IsDB) & $\begin{array}{l}\text { Islamic Economics } \\
(1421 \mathrm{H} / 2001)\end{array}$ \\
\hline $\begin{array}{l}\text { Sheikh Saeed Ahmed } \\
\text { Lootah }\end{array}$ & UAE & The founder of the world's first Islamic bank & $\begin{array}{l}\text { Islamic Banking and } \\
\text { Finance }(1422 \mathrm{H} / 2002)\end{array}$ \\
\hline Prof. John Presley & UK & Emeritus Professor, Loughborough University & $\begin{array}{l}\text { Islamic Banking and } \\
\text { Finance }(1422 \mathrm{H} / 2002)\end{array}$ \\
\hline Dr. Abbas Mirakhor & Iran & First Holder, INCEIF Chair of Islamic Finance & $\begin{array}{l}\text { Islamic Economics } \\
(1423 \mathrm{H} / 2003)\end{array}$ \\
\hline Dr. Mohsin Khan & Pakistan & $\begin{array}{l}\text { Senior Fellow, The Rafik Hariri Center for the Middle East } \\
\text { at the Atlantic Council in Washington DC }\end{array}$ & $\begin{array}{l}\text { Islamic Economics } \\
(1423 \mathrm{H} / 2003)\end{array}$ \\
\hline $\begin{array}{l}\text { Dr. Mohammad Ali Al } \\
\text { Qari }\end{array}$ & Saudi & $\begin{array}{l}\text { Chairman and Member of IFIs' } \\
\text { Shari'ah Supervisory Boards, Saudi Arabia }\end{array}$ & $\begin{array}{l}\text { Islamic Banking and } \\
\text { Finance }(1424 \mathrm{H} / 2004)\end{array}$ \\
\hline $\begin{array}{l}\text { Dr. Shawqi Ahmed } \\
\text { Dunya }\end{array}$ & Egypt & $\begin{array}{l}\text { Professor } \\
\text { The Azhar University }\end{array}$ & $\begin{array}{l}\text { Islamic Economics } \\
(1425 \mathrm{H} / 2005)\end{array}$ \\
\hline $\begin{array}{l}\text { Prince Mohamad Alfaisal } \\
\text { Al Saud }\end{array}$ & $\begin{array}{l}\text { Saudi } \\
\text { Arabia }\end{array}$ & President, Al Faisaliah Group Holding & $\begin{array}{l}\text { Islamic Banking and } \\
\text { Finance }(1426 \mathrm{H} / 2006)\end{array}$ \\
\hline $\begin{array}{l}\text { Dr. Abdussalam Dawoud } \\
\text { Al-Abbadi }\end{array}$ & Jordan & $\begin{array}{l}\text { Secretary-General, The International } \\
\text { Islamic Fiqh Academy }\end{array}$ & $\begin{array}{l}\text { Islamic Economics } \\
(1427 \mathrm{H} / 2007)\end{array}$ \\
\hline $\begin{array}{l}\text { Sheikh Mohammed } \\
\text { Mukhtar Al Salami }\end{array}$ & Tunisia & Shari'ah Expert & $\begin{array}{l}\text { Islamic Banking and } \\
\text { Finance }(1428 \mathrm{H} / 2008)\end{array}$ \\
\hline $\begin{array}{l}\text { Sheikh Abdullah Bin } \\
\text { Sulaiman Al Manee' }\end{array}$ & $\begin{array}{l}\text { Saudi } \\
\text { Arabia }\end{array}$ & Advisor, Royal Court and Senior Ulama Board & $\begin{array}{l}\text { Islamic Banking and } \\
\text { Finance }(1428 \mathrm{H} / 2008)\end{array}$ \\
\hline Dr. Zubair Hasan & India & Professor Emeritus (INCEIF) & $\begin{array}{l}\text { Islamic Economics } \\
(1430 \mathrm{H} / 2009)\end{array}$ \\
\hline $\begin{array}{l}\text { Prof Rifaat Ahmad } \\
\text { Abdul Karim }\end{array}$ & Sudan & Secretary General of AAOIFI & $\begin{array}{l}\text { Islamic Banking and } \\
\text { Finance }(1431 \mathrm{H} / 2010)\end{array}$ \\
\hline $\begin{array}{l}\text { Tan Sri Dr. Zeti Akhtar } \\
\text { Aziz }\end{array}$ & Malaysia & ASB Board of Governors & $\begin{array}{l}\text { Islamic Banking and } \\
\text { Finance }(1433 \mathrm{H} / 2012)\end{array}$ \\
\hline Sheikh Taqi Usmani & Pakistan & Vice President \& Hadith Professor, Darul Uloom Karachi & $\begin{array}{l}\text { Islamic Banking and } \\
\text { Finance }(1435 \mathrm{H} / 2014)\end{array}$ \\
\hline
\end{tabular}




\begin{tabular}{|c|c|c|c|}
\hline Prof. Rodeny Wilson & UK & Emeritus Professor of Economics, Durham University & $\begin{array}{l}\text { Islamic Banking and } \\
\text { Finance }(1435 \mathrm{H} / 2014)\end{array}$ \\
\hline $\begin{array}{l}\text { Dr. Saif El din } \\
\text { Ibrahim Taj El din }\end{array}$ & UK & Professor & $\begin{array}{l}\text { Islamic Economics } \\
(1436 \mathrm{H} / 2015)\end{array}$ \\
\hline $\begin{array}{l}\text { Dr. Mohammad Kabir } \\
\text { Hassan }\end{array}$ & USA & $\begin{array}{l}\text { Chairs-Hibernia Professor of Economics and Finance, } \\
\text { Hancock Whitney Chair Professor in Business, and Bank } \\
\text { One Professor in Business, University of New Orleans }\end{array}$ & $\begin{array}{l}\text { Islamic Banking and } \\
\text { Finance }(1437 \mathrm{H} / 2016)\end{array}$ \\
\hline Dr. Ahmed Ali Abdullah & Sudan & AAOIFI \& Emirates NBD Bank Member & $\begin{array}{l}\text { Islamic Banking and } \\
\text { Finance }(1439 \mathrm{H} / 2018)\end{array}$ \\
\hline Dr. Mabid Ali al-Jarhi & Egypt & Shariah Board Member at Dubai Financial Market & $\begin{array}{l}\text { Islamic Economics, } \\
\text { Banking and Finance } \\
(1440 \mathrm{H} / 2019)\end{array}$ \\
\hline
\end{tabular}

Source: Islamic Research and Training Institute (2021)

records for other IsDB scholars, who have enriched the Islamic economics, banking, and finance field through other types of publications, as well as their professional and regulatory contributions towards the development of this field in Table 4B.

Figure 4 shows 12 years of data collected from Google Scholars because the use of this search engine is widespread within the academic world. The academic community will profit from the development of the specialised Google Scholar search service, since it can bring to their attention content that is more relevant to their needs. The large number of websites that hold potentially relevant information necessitates a search engine that can search through millions of sites, while also focusing on extremely particular categories of information (Frederick J. Friend, 2006). Since 2010, Professor M. Kabir Hassan has released numerous research articles, books, and journals, and participated in conferences while based at the University of New Orleans, USA. Following in his footsteps is Professor Mohamed Ariff Syed Mohamed from Universiti Kuala Lumpur Business School, Malaysia. Meanwhile, the number of research papers published in big formats has increased dramatically since 2015 for Professor Abul Mansur M. Masih.

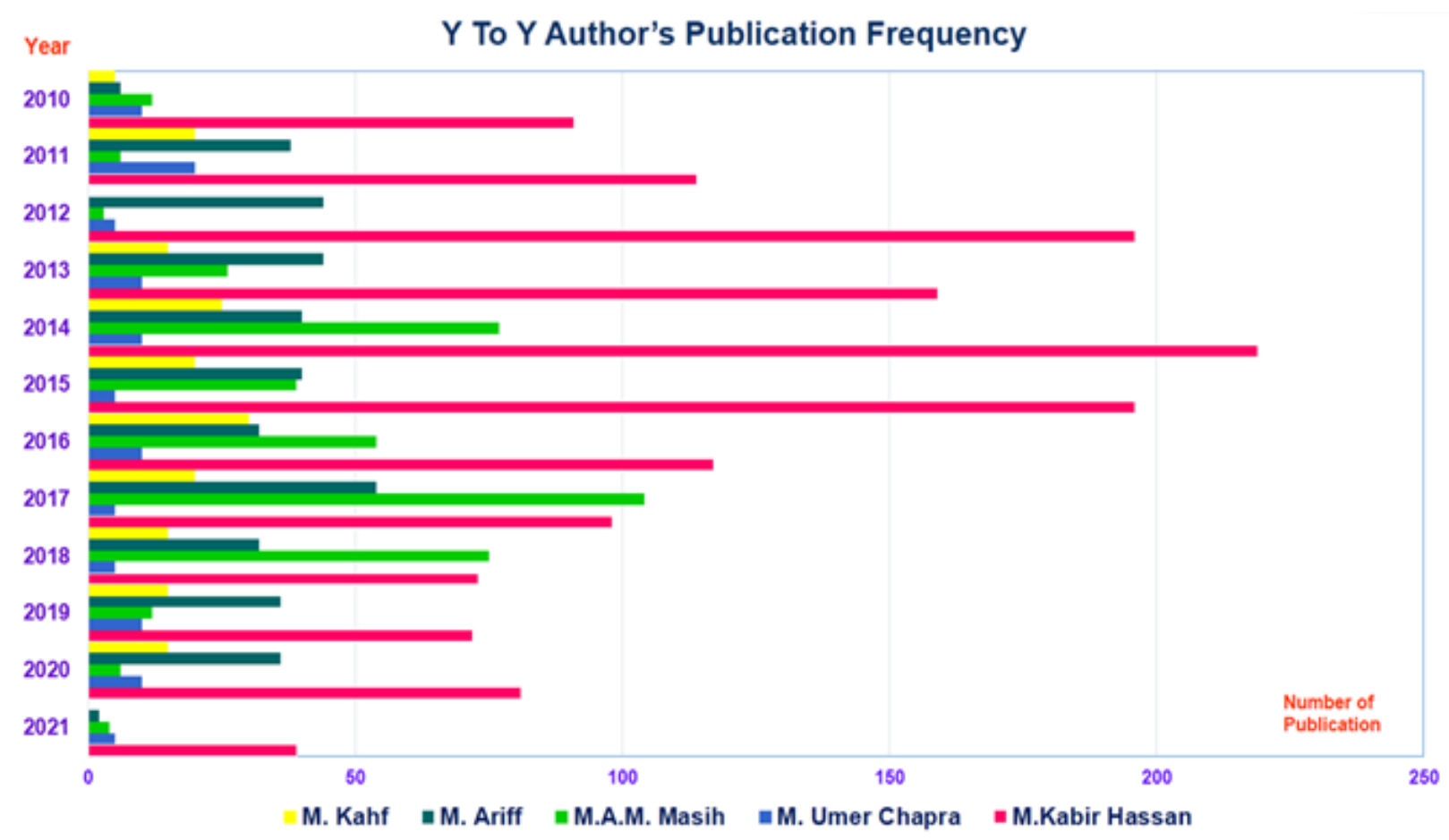

FIGURE 4. Year to Year Author's Publication Frequency (2010-2021)

Source: Author Adopted (Data Processed from Google Scholar, July 2021, all inclusive) 


\section{THE CO-AUTHORSHIP PATTERN AND COLLABORATORS}

Multiple authorship is a well-known element in modern science publications and there has been an upward trend towards more collaborations in all fields of science over the last century (Karisiddappa et al. 1990). This can be seen in Figure 5 that shows 320 of the 346 articles having multi-authorship, whereas only 26 publications have solo authorship.

Figure 5 also shows how the VOSviewer technique is used to perform a density visualisation of author cocitation analysis (ACA) for the top 292 active authors. Based on a minimum of 100 citations per author, the final number of authors considered in this study was 50 .

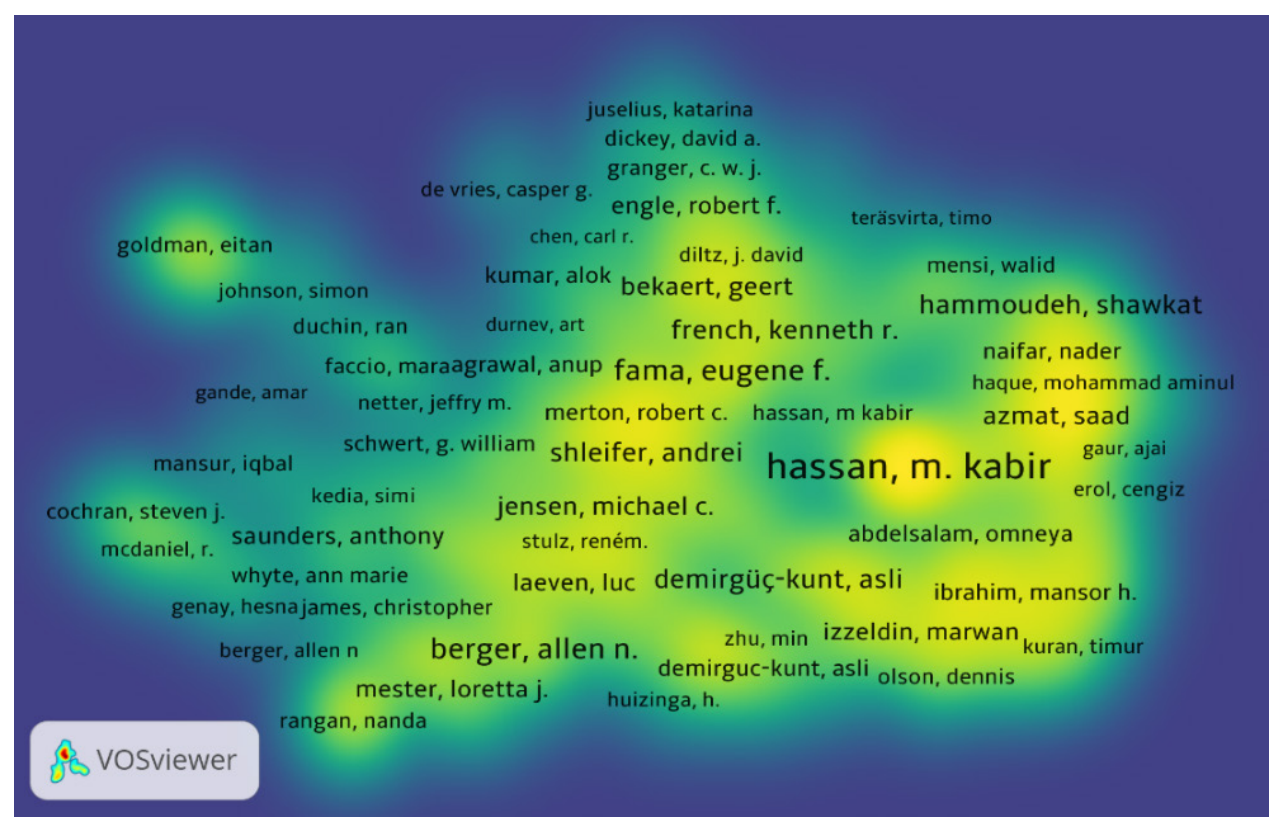

FIGURE 5. The density visualisation of co-authors Source: Author Adopted (Data Processed from VOSViwer, July 2021)

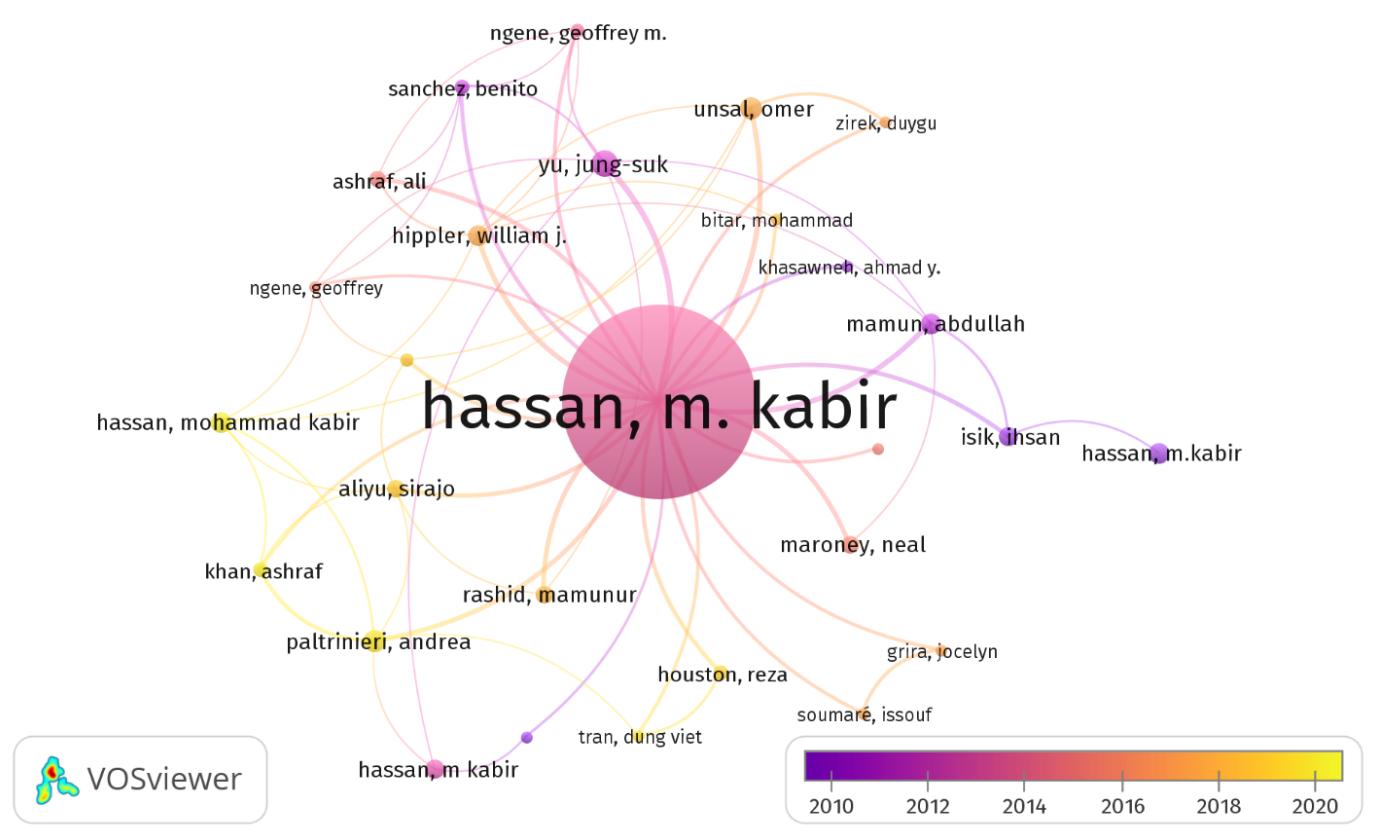

FIGURE. 6. The Most Prolific Islamic Finance Authors in Collaborative Network Nodes Source: Author Adopted (Data Processed from VOSViwer, July 2021) 


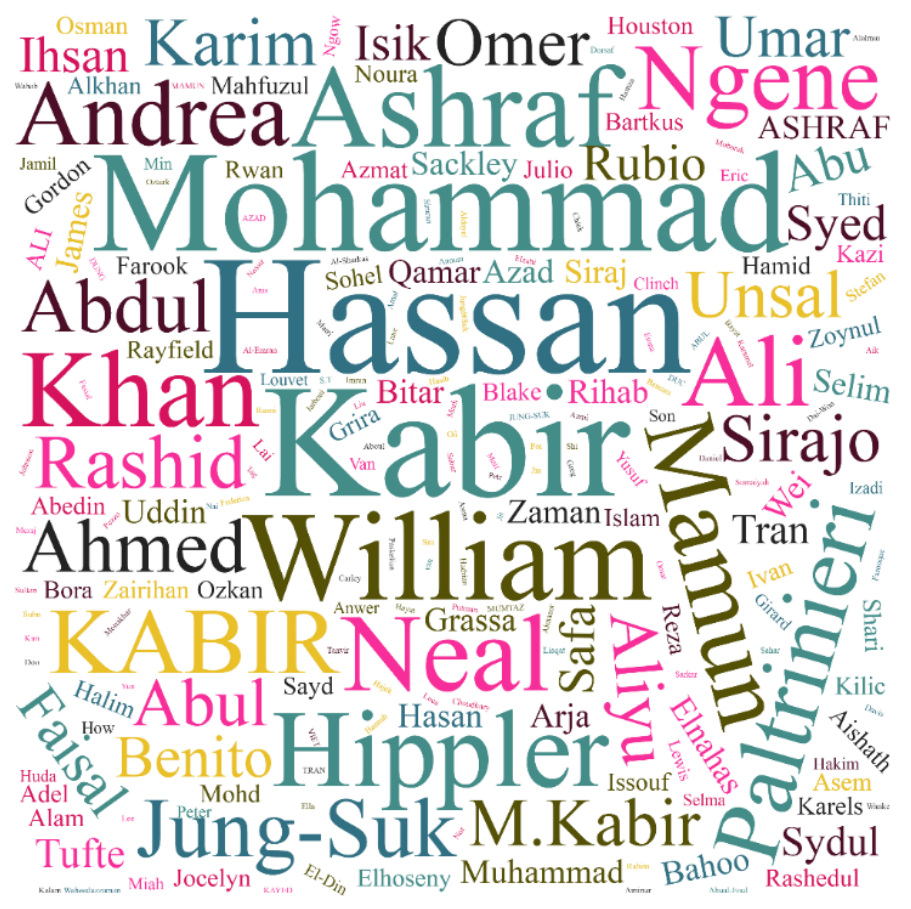

FIGURE 7. Word Clouds that Represent Contributions by Prolific Authors Source: Author Adopted (Data Processed from WordClouds, July 2021)

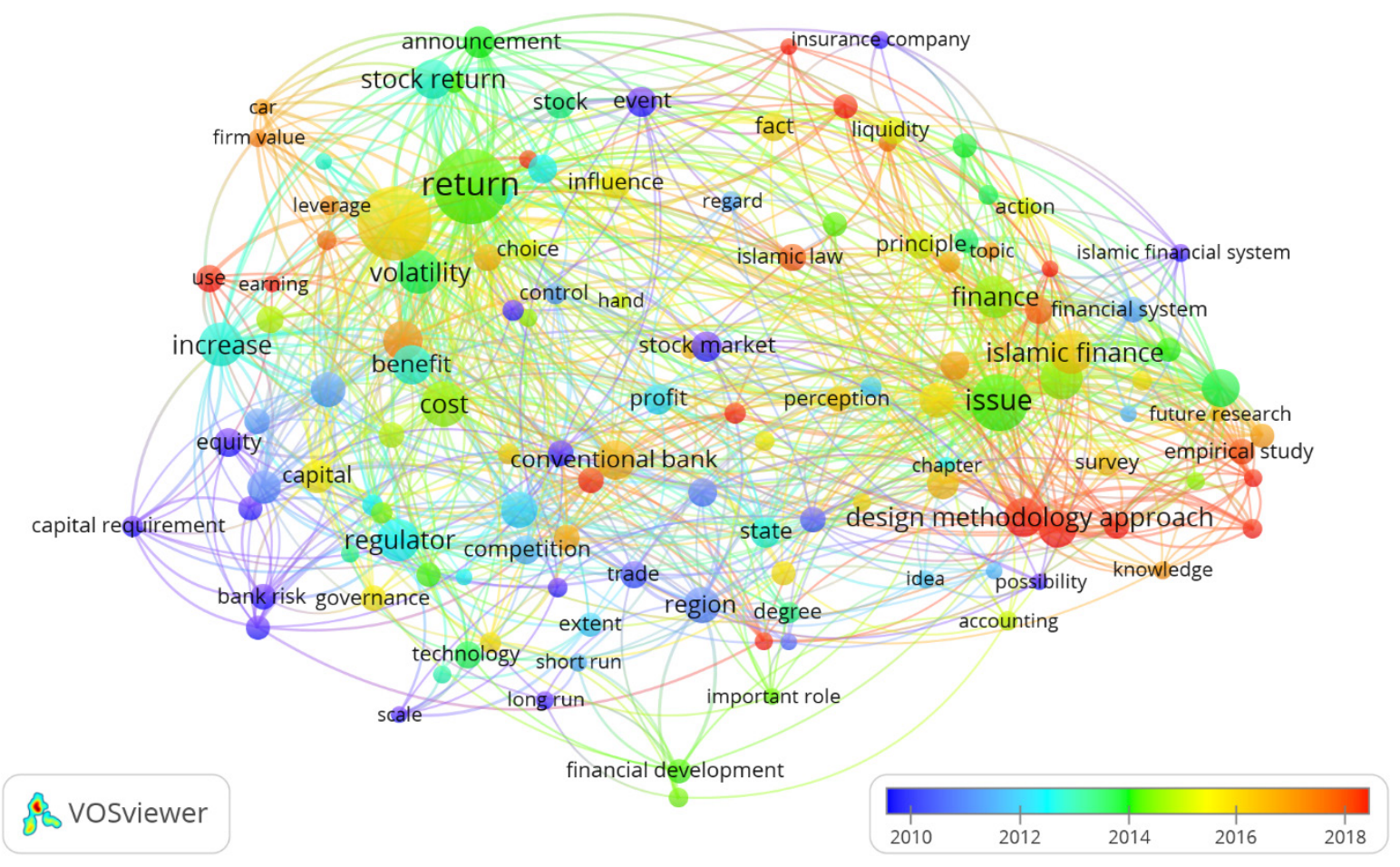

FIGURE 8. The cloud map network developed from the word clouds Source: Author Adopted (Data Processed from VOSViwer, July 2021) 
The right-hand bell-shaped area showing a significant number of yellow portions represents active authors, who have collaboratively worked with Professor M. Kabir Hassan. The middle area of the image density visualisation shows that they are actively conducting research work.

Figure 6 shows the global network of research scholars, who are conducting research and collaborating with Professor M. Kabir Hassan. A single author and two authors are represented by different nodes, with their organisations being considered if they co-authored a paper. The intensity of linkages represents the level of collaboration between two nodes, whereas the size of the nodes indicates their degree of centrality. These nodes are colour-coded to represent prolific research scholars (authors): Professor M. Kabir Hassan (pink); Jung Suk-Yu (dark pink); Andrea Paltrinieri (yellow); Omer Unsal (orange); William J. Hippler (light orange); and Abdullah Mamun (light purple).

Figure 7 shows word clouds that are based on publication frequencies and the authors who have worked on at least five papers with Professor M. Kabir Hassan. He has co-authored 346 research articles with
292 collaborators, which resulted in 1,346 authorships. Professor M. Kabir Hassan shares 25.71\% (346/1,346) of these authorships, with an article fraction of 117.27, while the rest of the co-authors collectively share $74.29 \%$. Table 5 lists the co-authorship network, which can be used to track down notable scientists in the field of Islamic finance.

This study has discovered that 292 authors have published between one and 10 articles, 55 authors have contributed between 10 and 20 articles, while the remaining authors have published between five and 16 articles.

Figure 8 is similar to Figure 7, with the exception that it is binarily numbered. This means that regardless of how many times a word appears in a document, it will only be counted once. This can affect the results in the sense that if a word is frequently used in a text, the results are not overestimated. With binary counting, we found five main clusters in this cloud map. The main keywords used were Islamic finance, finance, stock and financial development (green), capital leverage, financial system, conventional bank (orange), control region, event, and stock market (red).

TABLE 5. The co-authorship network with Professor M. Kabir Hassan

\begin{tabular}{|c|c|c|}
\hline Author & NA & $\mathrm{AF}$ \\
\hline M. Kabir Hassan & 346 & 117.2 \\
\hline Jung Suk-Yu & 16 & 3.83 \\
\hline Andrea Paltrinieri & 12 & 2.06 \\
\hline Omer Unsal & 12 & 2.61 \\
\hline William J. Hippler & 11 & 2.21 \\
\hline Adullah Mamun & 11 & 2.27 \\
\hline Ashraf Khan & 7 & 2.03 \\
\hline Sirajo Aliyo & 9 & 2.01 \\
\hline Ihsan Isik & 10 & 2.11 \\
\hline Ali Ashraf & 8 & 2.09 \\
\hline Benito Sancez & 7 & 2.17 \\
\hline Geoffrey M. Nggene & 6 & 1.98 \\
\hline Mamunur Rashid & 9 & 2.14 \\
\hline Jocelyn Gerira & 5 & 1.97 \\
\hline Reza Houston & 7 & 2.18 \\
\hline Neal Maroney & 9 & 2.33 \\
\hline Issouf Somare & 5 & 1.91 \\
\hline Jennifer Broadman & 6 & 2.66 \\
\hline Dung Viet Tran & 5 & 2.32 \\
\hline Duyugu Zirek & 5 & 1.91 \\
\hline M.Kabir & 5 & 2.39 \\
\hline Geoffrey Nggene & 5 & 1.95 \\
\hline Mohammad Bittar & 5 & 1.71 \\
\hline Ahmad Y. Khasawneh & 5 & 1.79 \\
\hline Umar A. Oseni & 5 & 2.21 \\
\hline Oscar Varela & 5 & 2.03 \\
\hline Other 266 authors & 810 & \\
\hline Total & 1,346 & \\
\hline
\end{tabular}

Source: Author Adopted

* NA: Number of Authorship. AF: Article Fractionalised 
THE INFLUENCE OF PROFESSOR M. KABIR HASSAN'S PUBLICATIONS

As shown in Table 6A, Professor M. Kabir Hassan's research works have been impactful and have influenced researchers from different parts of the world, including the United States, the United Kingdom, South Korea,
Australia, Egypt, Sweden, and Malaysia. Papers he published that are influencing Scopus top 20 cited articlejournal with impact factor, category, and publishing country were considered in this study. Tables $6 \mathrm{~B}$ to $6 \mathrm{D}$ list his forthcoming papers, popular scholarly books he co-authored, and popular textbooks, respectively.

TABLE 6A. The influence of Professor M. Kabir Hassan's publications on the world

\begin{tabular}{|c|c|c|c|c|}
\hline Journal & $\begin{array}{c}\text { Article } \\
\text { Publication } \\
\text { Year } \\
\end{array}$ & Cited & $\begin{array}{l}\text { Impact Factor/ Category/ } \\
\text { Publishing Country }\end{array}$ & $\begin{array}{l}\text { Co-Author's } \\
\text { Affiliated Country }\end{array}$ \\
\hline $\begin{array}{l}\text { The Quarterly Review of Economics and } \\
\text { Finance }\end{array}$ & $\begin{array}{l}1993,1994 \\
2003,2007 \\
2008,2011 \\
2018,2019\end{array}$ & 860 & 2.619/Q2/ Netherlands & The United States \\
\hline Journal of Banking and Finance & $\begin{array}{l}1994,2002 \\
2003,2005\end{array}$ & 779 & 3.07/Q1/ Netherlands & The United States \\
\hline $\begin{array}{l}\text { Journal of Islamic Accounting and Business } \\
\text { Research }\end{array}$ & $\begin{array}{l}2010,2011 \\
2017,2020\end{array}$ & 444 & 1.69/Q3/ United Kingdom & $\begin{array}{l}\text { The United States, } \\
\text { Australia }\end{array}$ \\
\hline $\begin{array}{l}\text { International Journal of Islamic and Middle } \\
\text { Eastern Finance and Management }\end{array}$ & $\begin{array}{l}2009,2011, \\
2012,2013, \\
2014,2018, \\
2019\end{array}$ & 292 & 2.84/Q2/ United Kingdom & $\begin{array}{l}\text { Australia, } \\
\text { Bangladesh, Egypt, } \\
\text { Malaysia, Morocco, } \\
\text { Pakistan, Spain, the } \\
\text { United States, }\end{array}$ \\
\hline Journal of Business Finance \& Accounting & $\begin{array}{l}2003,2005 \\
2008\end{array}$ & 263 & 3.07/Q1/ Netherlands & The United States \\
\hline Financial Review & 2002 & 230 & 1.09/Q2/ United States & The United States \\
\hline $\begin{array}{l}\text { International Review of Economics and } \\
\text { Finance }\end{array}$ & $\begin{array}{l}1994,1996 \\
2019,2020\end{array}$ & 222 & 1.42/Q2/ United States & $\begin{array}{l}\text { Italy, Norway, } \\
\text { Malaysia, Pakistan, } \\
\text { the United States }\end{array}$ \\
\hline Financial Management & 2003 & 217 & 1.80/Q1 / United Kingdom & The United States \\
\hline $\begin{array}{l}\text { Research in International Business and } \\
\text { Finance }\end{array}$ & 2018 & 214 & 4.091/Q1/ Netherlands & $\begin{array}{l}\text { South Korea, the } \\
\text { United States }\end{array}$ \\
\hline Journal of Financial Services Research & $\begin{array}{l}1992,1999, \\
2017\end{array}$ & 210 & $\begin{array}{l}\text { 2.473/Q1 / United } \\
\text { Kingdom }\end{array}$ & $\begin{array}{l}\text { The United States, } \\
\text { the United Kingdom, } \\
\text { Australia }\end{array}$ \\
\hline $\begin{array}{l}\text { Financial Markets Institutions and } \\
\text { Instruments }\end{array}$ & 2001 & 189 & 1.09/Q2 / United Kingdom & The United States \\
\hline Expert Systems with Applications & 2017 & 181 & $\begin{array}{l}\text { 6.954/Q1/ United } \\
\text { Kingdom }\end{array}$ & $\begin{array}{l}\text { The United States, } \\
\text { UAE }\end{array}$ \\
\hline Journal of Asian Economics & 2001 & 179 & 2.17/Q2/ Netherlands & The United States \\
\hline Thunderbird International Business Review & $\begin{array}{l}2007,2011 \\
2012,2019\end{array}$ & 160 & 1.84/Q1/ United States & $\begin{array}{l}\text { The United States, } \\
\text { Australia, Palestine }\end{array}$ \\
\hline Journal of Financial Stability & $\begin{array}{l}2015,2017, \\
2018,2020\end{array}$ & 142 & 3.727/Q1/ Netherlands & $\begin{array}{l}\text { The United States, } \\
\text { Malaysia }\end{array}$ \\
\hline Pacific-Basin Finance Journal & $\begin{array}{l}2004,2011, \\
2014,2015, \\
2020\end{array}$ & 142 & 2.514/Q2/ Netherlands & $\begin{array}{l}\text { Pakistan, Malaysia, } \\
\text { the United States, } \\
\text { Saudi Arabia }\end{array}$ \\
\hline $\begin{array}{l}\text { Journal of King Abdulaziz University: } \\
\text { Islamic Economics }\end{array}$ & $\begin{array}{l}2010,2011, \\
2013,2015\end{array}$ & 135 & 0.22/Q3/ Saudi Arabia & $\begin{array}{l}\text { The United States, } \\
\text { Saudi Arabia }\end{array}$ \\
\hline
\end{tabular}




\begin{tabular}{|c|c|c|c|c|}
\hline Emerging Markets Finance and Trade & $\begin{array}{l}2016,2017 \\
2019\end{array}$ & 132 & $1.214 / \mathrm{Q} 1 /$ United States & $\begin{array}{l}\text { Tunisia, UAE, } \\
\text { the United States, } \\
\text { France, Canada, } \\
\text { Saudi Arabia }\end{array}$ \\
\hline $\begin{array}{l}\text { International Review of Economics \& } \\
\text { Finance }\end{array}$ & 1996 & 124 & 1.42/Q2 / United Kingdom & The United States \\
\hline The Journal of Investing & 2008 & 104 & 0.33/Q3 / United Kingdom & The United States \\
\hline Borsa Istanbul Review & $\begin{array}{l}2013,2016, \\
2017,2018, \\
2019,2020\end{array}$ & 66 & 3.92/Q2/ Turkey & $\begin{array}{l}\text { Malaysia, the United } \\
\text { States }\end{array}$ \\
\hline
\end{tabular}

Source: Author Adopted (Data Processed from Scopus, Web of Science, Google Scholars, July 2021)

TABLE 6B. Forthcoming journal publication list

\begin{tabular}{|c|c|c|c|}
\hline Title & Journal & Status/ Year & $\begin{array}{l}\text { Impact Factor/Category/ } \\
\text { Publication Country }\end{array}$ \\
\hline $\begin{array}{l}\text { Islamic banking stability amidst the } \\
\text { Covid- } 19 \text { pandemic: the role of digital } \\
\text { financial inclusion }\end{array}$ & $\begin{array}{l}\text { International Journal of Islamic } \\
\text { and Middle Eastern Finance and } \\
\text { Management (IMEFM) }\end{array}$ & $\begin{array}{l}\text { Forthcoming } \\
2021\end{array}$ & 2.68/Q2/the United Kingdom \\
\hline $\begin{array}{l}\text { A Bibliometric Review of Waqf } \\
\text { Literature }\end{array}$ & Eurasian Economic Review & Accepted 2021 & 0.62 /Q2/ Switzerland \\
\hline $\begin{array}{l}\text { Islamic Microfinance: A Bibliometric } \\
\text { Review }\end{array}$ & The Global Finance Journal & Accepted 2021 & 2.79/Q2 Netherlands \\
\hline $\begin{array}{l}\text { Ten years of the Journal of Islamic } \\
\text { Accounting and Business Research: A } \\
\text { Bibliometric Analysis, }\end{array}$ & $\begin{array}{l}\text { Collnet Journal of Scientometrics } \\
\text { and Information Management }\end{array}$ & Accepted 2021 & 1.99/Q2/the United Kingdom \\
\hline $\begin{array}{l}\text { Safe Havens in Islamic Financial } \\
\text { Markets: COVID-19 versus GFC }\end{array}$ & The Global Finance Journal & Accepted 2021 & 2.79/Q2 Netherlands \\
\hline $\begin{array}{l}\text { Ten Years of Journal of Islamic } \\
\text { Marketing: A Bibliometric Analysis }\end{array}$ & Journal of Islamic Marketing & Accepted 2021 & 3.42/Q2/the United Kingdom \\
\hline $\begin{array}{l}\text { Corruption and Bank Efficiency: } \\
\text { Expanding the "Sand or Grease the } \\
\text { Wheel Hypothesis" for Islamic and } \\
\text { conventional banks }\end{array}$ & Journal of Public Affairs & Accepted 2021 & 1.08/Q3/the United States \\
\hline $\begin{array}{l}\text { Impact of COVID-19 Pandemic on } \\
\text { Stock Markets: Conventional vs. Islamic } \\
\text { Indices using Wavelet-based Multi- } \\
\text { timescale Analysis. }\end{array}$ & $\begin{array}{l}\text { North American Journal of } \\
\text { Economics and Finance. }\end{array}$ & Accepted 2021 & $1.535 / \mathrm{Q} 3 /$ the United States \\
\hline $\begin{array}{l}\text { Do Financial Stability and Competition } \\
\text { Differ in Islamic and Conventional } \\
\text { Banking? An Empirical Evidence from } \\
\text { Pakistan. }\end{array}$ & $\begin{array}{l}\text { International Journal of Business } \\
\text { and Society }\end{array}$ & Accepted 2021 & 0.92/Q3 Malaysia \\
\hline $\begin{array}{l}\text { Integrating Islamic finance and Halal } \\
\text { industry: Current landscape and future } \\
\text { forward }\end{array}$ & $\begin{array}{l}\text { International Journal of Islamic } \\
\text { Marketing and Branding }\end{array}$ & Accepted 2021 & 1.09/Q3/ Jordan \\
\hline $\begin{array}{l}\text { A Hybrid Review of Islamic Pricing } \\
\text { Literature }\end{array}$ & Singapore Economic Review & Accepted 2021 & 0.88/Q3/ Singapore \\
\hline
\end{tabular}

Source: Author Adopted (Data Processed from Scopus, Web of Science, Google Scholars, July 2021) 
TABLE 6C. Popular scholarly books by Professor M. Kabir Hassan

\begin{tabular}{|c|c|c|c|c|}
\hline Author(s) & Book Title & Year & Publisher & $\begin{array}{l}\text { Co-Author's Affiliated } \\
\text { Country }\end{array}$ \\
\hline $\begin{array}{l}\text { M. Kabir Hassan, Aishath } \\
\text { Muneeza, \& Adel Sarea }\end{array}$ & $\begin{array}{l}\text { COVID-19 and the Islamic } \\
\text { Financial System: The Role of } \\
\text { Islamic Finance }\end{array}$ & $\begin{array}{l}\text { The United } \\
\text { Kingdom } 2022\end{array}$ & $\begin{array}{l}\text { Emerald } \\
\text { Publishing }\end{array}$ & $\begin{array}{l}\text { The United States, } \\
\text { Maldives, Bahrain }\end{array}$ \\
\hline $\begin{array}{l}\text { M. Kabir Hassan, Mehmet } \\
\text { Saraç, \& Ashraf Khan }\end{array}$ & $\begin{array}{l}\text { Sustainable Development Goals } \\
\text { and Islamic Finance }\end{array}$ & $\begin{array}{l}\text { The United } \\
\text { States } 2021\end{array}$ & $\begin{array}{l}\text { Palgrave- } \\
\text { McMillan }\end{array}$ & $\begin{array}{l}\text { The United States, } \\
\text { Turkey, Pakistan }\end{array}$ \\
\hline $\begin{array}{l}\text { Noura Metawa, M. Kabir } \\
\text { Hassan, \& Saad Metawa }\end{array}$ & $\begin{array}{l}\text { Artificial Intelligence and } \\
\text { Big Data for Financial Risk } \\
\text { Management: Intelligent } \\
\text { Applications }\end{array}$ & $\begin{array}{l}\text { The United } \\
\text { Kingdom } 2021\end{array}$ & $\begin{array}{l}\text { Taylor and } \\
\text { Francis }\end{array}$ & $\begin{array}{l}\text { Egypt, the United } \\
\text { States }\end{array}$ \\
\hline $\begin{array}{l}\text { Mohammad Zoynul Abedin, } \\
\text { M. Kabir Hassan, Petr } \\
\text { Hajek, \& Mohammed Mohi } \\
\text { Uddin }\end{array}$ & $\begin{array}{l}\text { The Essentials of Machine } \\
\text { Learning in Finance and } \\
\text { Accounting }\end{array}$ & $\begin{array}{l}\text { The United } \\
\text { Kingdom } 2021\end{array}$ & $\begin{array}{l}\text { Taylor and } \\
\text { Francis }\end{array}$ & $\begin{array}{l}\text { Bangladesh, Czech } \\
\text { Republic, the United } \\
\text { States }\end{array}$ \\
\hline $\begin{array}{l}\text { M. Kabir Hassan, Aishath } \\
\text { Muneeza, \& } \\
\text { Adel Sarea }\end{array}$ & $\begin{array}{l}\text { Impact of COVID-19 and Islamic } \\
\text { Social Finance }\end{array}$ & $\begin{array}{l}\text { Singapore } \\
2020\end{array}$ & $\begin{array}{l}\text { Taylor and } \\
\text { Francis }\end{array}$ & $\begin{array}{l}\text { The United States, } \\
\text { Maldives, Bahrain }\end{array}$ \\
\hline $\begin{array}{l}\text { John Sandwick, M. Kabir } \\
\text { Hassan, \& Pablo Collazzo }\end{array}$ & $\begin{array}{l}\text { A Guide to Islamic Asset } \\
\text { Management: Portfolio Investing } \\
\text { with Sharia }\end{array}$ & $\begin{array}{l}\text { The United } \\
\text { States } 2020\end{array}$ & Edward Elgar & The United States \\
\hline $\begin{array}{l}\text { M. Kabir Hassan \& Mehmet } \\
\text { Saraç }\end{array}$ & $\begin{array}{l}\text { Islamic Perspectives on } \\
\text { Sustainable Financial System }\end{array}$ & Turkey 2020 & $\begin{array}{l}\text { Istanbul } \\
\text { University Press } \\
\text { (IUPRESS) }\end{array}$ & $\begin{array}{l}\text { The United States, } \\
\text { Turkey }\end{array}$ \\
\hline M. Kabir Hassan et al. & $\begin{array}{l}\text { Machine Learning in Finance: } \\
\text { Current state-of-the-art and } \\
\text { Beyond: Integration of machine } \\
\text { learning algorithms in financial } \\
\text { product modelling }\end{array}$ & $\begin{array}{l}\text { The United } \\
\text { Kingdom } 2021\end{array}$ & $\begin{array}{l}\text { Taylor and } \\
\text { Francis, } 2021\end{array}$ & The United States \\
\hline $\begin{array}{l}\text { Khalifa Mohamed Ali, } \\
\text { M. Kabir Hassan, \& Abd } \\
\text { elrahman Elzahi Saaid Ali }\end{array}$ & $\begin{array}{l}\text { Revitalization of Waqf for Socio- } \\
\text { Economic Development }\end{array}$ & $\begin{array}{l}\text { The United } \\
\text { States } 2019\end{array}$ & $\begin{array}{l}\text { Palgrave- } \\
\text { MacMillan, } \\
\text { August 22, }\end{array}$ & $\begin{array}{l}\text { Saudi Arabia, the } \\
\text { United States }\end{array}$ \\
\hline $\begin{array}{l}\text { Noura Metawa, Aboul } \\
\text { Ella Hassanien, M. Kabir } \\
\text { Hassan, \& Mohamed } \\
\text { Elhoseny Francis }\end{array}$ & $\begin{array}{l}\text { Expert Systems in Finance: Smart } \\
\text { Financial Applications in Big } \\
\text { Data Environments }\end{array}$ & $\begin{array}{l}\text { The United } \\
\text { Kingdom } 2019\end{array}$ & $\begin{array}{l}\text { Taylor and } \\
\text { Francis }\end{array}$ & $\begin{array}{l}\text { Egypt, the United } \\
\text { States }\end{array}$ \\
\hline $\begin{array}{l}\text { Umar A. Oseni, M. Kabir } \\
\text { Hassan, \& Rusni Hassan }\end{array}$ & $\begin{array}{l}\text { Emerging Issues in Islamic } \\
\text { Finance, and Law and Practice in } \\
\text { Malaysia }\end{array}$ & Malaysia 2019 & $\begin{array}{l}\text { Emerald } \\
\text { Publishing }\end{array}$ & $\begin{array}{l}\text { Malaysia, the United } \\
\text { States }\end{array}$ \\
\hline $\begin{array}{l}\text { M. Kabir Hassan, Mamunur } \\
\text { Rashid, \& Sirajo Aliyu }\end{array}$ & Islamic Corporate Finance & $\begin{array}{l}\text { The United } \\
\text { Kingdom } 2019\end{array}$ & $\begin{array}{l}\text { Taylor and } \\
\text { Francis }\end{array}$ & $\begin{array}{l}\text { The United States, } \\
\text { Maldives, Bahrain }\end{array}$ \\
\hline $\begin{array}{l}\text { Ahcene Lahsasan, M. Kabir } \\
\text { Hassan, \& Rubi Ahmed }\end{array}$ & $\begin{array}{l}\text { Forward Lease Sukuk in Islamic } \\
\text { Capital Market: Structure and } \\
\text { Governing Rules, Palgrave- } \\
\text { Springer, } 2018\end{array}$ & $\begin{array}{l}\text { The United } \\
\text { States } 2018\end{array}$ & $\begin{array}{l}\text { Palgrave- } \\
\text { McMillan }\end{array}$ & $\begin{array}{l}\text { Malaysia, the United } \\
\text { States }\end{array}$ \\
\hline M. Kabir Hassan & $\begin{array}{l}\text { Edward Elgar Publishing } \\
\text { Company }\end{array}$ & $\begin{array}{l}\text { The United } \\
\text { Kingdom } 2017\end{array}$ & $\begin{array}{l}\text { Edward Elgar } \\
\text { Publishing } \\
\text { Company }\end{array}$ & The United States \\
\hline $\begin{array}{l}\text { M. Kabir Hassan \& Mervyn } \\
\text { K. Lewis }\end{array}$ & $\begin{array}{l}\text { Handbook on Islam and } \\
\text { Economic Life }\end{array}$ & $\begin{array}{l}\text { The United } \\
\text { Kingdom } 2017\end{array}$ & $\begin{array}{l}\text { Edward Elgar } \\
\text { Publishing } \\
\text { Company }\end{array}$ & The United States \\
\hline $\begin{array}{l}\text { M. Kabir Hassan \& Michael } \\
\text { Mahlknecht }\end{array}$ & $\begin{array}{l}\text { Islamic Capital Markets: Products } \\
\text { and Strategies }\end{array}$ & $\begin{array}{l}\text { The United } \\
\text { States } 2011\end{array}$ & $\begin{array}{l}\text { John Wiley and } \\
\text { Company }\end{array}$ & The United States \\
\hline
\end{tabular}




\begin{tabular}{|c|c|c|c|c|}
\hline $\begin{array}{l}\text { Rasem N. Kayed \& M. } \\
\text { Kabir Hassan }\end{array}$ & Islamic Entrepreneurship & $\begin{array}{l}\text { The United } \\
\text { Kingdom } 2010\end{array}$ & $\begin{array}{l}\text { Routledge } \\
\text { Publishing } \\
\text { Company }\end{array}$ & $\begin{array}{l}\text { The United States, } \\
\text { New Zealand }\end{array}$ \\
\hline $\begin{array}{l}\text { M. Kabir Hassan \& Mervyn } \\
\text { Lewis }\end{array}$ & Handbook of Islamic Banking & $\begin{array}{l}\text { The United } \\
\text { States } 2007\end{array}$ & $\begin{array}{l}\text { Edward Elgar } \\
\text { Publishing }\end{array}$ & The United States \\
\hline $\begin{array}{l}\text { M. Kabir Hassan \& Mervyn } \\
\text { Lewis }\end{array}$ & $\begin{array}{l}\text { The International Library of } \\
\text { Critical Writings in Economics }\end{array}$ & $\begin{array}{l}\text { The United } \\
\text { States } 2007\end{array}$ & $\begin{array}{l}\text { Edward Elgar } \\
\text { Publishing }\end{array}$ & The United States \\
\hline M. Kabir Hassan & $\begin{array}{l}\text { The Bangladesh Economy in the } \\
21 \text { st Century }\end{array}$ & $\begin{array}{l}\text { Bangladesh } \\
2007\end{array}$ & $\begin{array}{l}\text { Islamic Bank } \\
\text { Bangladesh } \\
\text { Limited }\end{array}$ & The United States \\
\hline $\begin{array}{l}\text { Rock Antoine-Mehanna \& } \\
\text { M. Kabir Hassan }\end{array}$ & $\begin{array}{l}\text { On Openness, Integration, and } \\
\text { Economic Growth. }\end{array}$ & $\begin{array}{l}\text { Bangladesh } \\
2003\end{array}$ & $\begin{array}{l}\text { Bangladesh } \\
\text { Institute of } \\
\text { Islamic Thought } \\
\text { (BIIT) }\end{array}$ & $\begin{array}{l}\text { The United States, } \\
\text { Lebanon }\end{array}$ \\
\hline M. Kabir Hassan & $\begin{array}{l}\text { Banking and Finance in } \\
\text { Bangladesh: A Collection of } \\
\text { Essays }\end{array}$ & $\begin{array}{l}\text { Bangladesh } \\
1995\end{array}$ & $\begin{array}{l}\text { Academic } \\
\text { Publishers }\end{array}$ & The United States \\
\hline
\end{tabular}

Source: Author Adopted (Data Processed from Scopus, Web of Science, Google Scholars, July 2021)

TABLE 6D. Popular text books co-authored by Professor M. Kabir Hassan

\begin{tabular}{|c|c|c|c|c|}
\hline Author(s) & Text Book Title & Year & Publisher & $\begin{array}{l}\text { Co-Author's Affiliated } \\
\text { Country }\end{array}$ \\
\hline $\begin{array}{l}\text { M. Kabir Hassan, } \\
\text { Salman Sheikh, and } \\
\text { Selim Kayhan }\end{array}$ & $\begin{array}{l}\text { Introduction to Islamic Banking } \\
\text { and Finance }\end{array}$ & Singapore 2020 & $\begin{array}{l}\text { World Scientific } \\
\text { Press }\end{array}$ & $\begin{array}{l}\text { The United States, } \\
\text { Pakistan }\end{array}$ \\
\hline $\begin{array}{l}\text { M. Kabir Hassan, } \\
\text { Rasem N. Kayed, and } \\
\text { Umar A. Oseni }\end{array}$ & Islamic Finance & $\begin{array}{l}\text { The United } \\
\text { Kingdom } 2010\end{array}$ & $\begin{array}{l}\text { Pearson Publishing } \\
\text { Company }\end{array}$ & $\begin{array}{l}\text { The United States, } \\
\text { Pakistan }\end{array}$ \\
\hline M. Kabir Hassan & A Textbook on Islamic Banking. & $\begin{array}{l}\text { Bangladesh } \\
2008\end{array}$ & $\begin{array}{l}\text { Islamic Economics } \\
\text { Research Bureau } \\
\text { (IERB) }\end{array}$ & The United States \\
\hline
\end{tabular}

Source: Author Adopted (Data Processed from Scopus, Web of Science, Google Scholars, July 2021)

\section{CONTENT ANALYSIS \& FUTURE RESEARCH DIRECTION}

The content analysis of Professor M. Kabir Hassan's research articles was divided into conceptual and empirical research. A summary of the main findings from these papers are presented in Table 7 (conceptual) and Table 8 (empirical).

Based on the above Tables 7 and 8 , it is evident that Professor M. Kabir Hassan has published research papers in different dimensions of Islamic finance, which includes Islamic social finance, such as zakat and waqf, as well as Islamic commercial finance and Islamic economic system.

The findings of these research papers are crucial for the theoretical developments of Islamic finance, as well as its practical developments as a distinctive discipline. He has consistently filled the gap in literature by contributing these research papers, which are bringing Islamic finance forward as a prominent field for research. We have derived several research areas for future research based on the research works published by Professor M. Kabir Hassan, as follows: i) the issue of Islamic common market that needs to be examined further in the light of new data and changing global perspectives; ii) a study on the issues faced by Islamic banks in adopting Basel III and capital adequacy framework for Islamic banks; iii) new models for takaful need to be explored; iv) the cost of faith-based investing needs to be studied in the recent times, especially to understand the impact of the pandemic on it; v) a study to understand the perception of the government of Bangladesh, and international and multilateral organisations on the role of zakat to alleviate poverty; vi) the level of technology adoption by Islamic banks can be studied; and vii) the successful implementation of equity-based Islamic finance contracts could be empirically studied. 
TABLE 7. Summary of the main findings of Professor M. Kabir Hassan's conceptual research papers on Islamic Finance

\begin{tabular}{cc}
\hline Year & Conceptual \\
\hline 2001 & $\begin{array}{l}\text { During this year, only one conceptual research paper was published. Below is the main finding made: } \\
\text { - In zakat administration, institutional factors, such as technology implementation and adopted policies play vital roles } \\
\text { that generate cooperative ventures between wage-labour and non-wage labour. }\end{array}$
\end{tabular}

2002 During this year, only one conceptual research paper was published. Below is the main finding made:

- There are unique legal issues that may trigger due to use of various Islamic finance instruments.

2006 During this year, two conceptual research papers were published. Below is the main finding made:

- The practical way zakat is considered as a retributive justice measure in Islam is important to be emphasized.

- Conventional time value of money is not applied in Islamic finance.

2007 During this year, three conceptual research papers were published. Below is the main finding made:

- A new takaful model that combines the concept of wakalah and waqf was proposed as an alternative in one of the research papers published in this year.

- There are lessons Australia could learn from the UK Finance Bill on Islamic finance.

- Bangladesh ought to reform their Islamic banking legal and supervisory framework.

2009 During this year, two conceptual research papers were published. Below is the main finding made:

- Legal and regulatory reforms in Australia are required to adopt in Islamic finance.

- Business success in Islamic finance was positively associated with the use of risk sharing or equity-based contracts.

2010 During this year, two conceptual research papers were published. Below is the main finding made:

- The future potentials of an Islamic common market need to be explored.

- In Saudi Arabic, entrepreneurship is considered as not only an economic duty, it is also considered as a religious duty, where obtaining income from halal (lawful) sources is a concern.

2011 During this year, three conceptual research papers were published. Below is the main finding made:

- Policymakers in Saudi Arabia need to emphasize entrepreneurship as a diversification strategy.

- Islamic finance is more resilient than conventional finance, whereby the implementation of pure Islamic finance principles could help resolve issues faced due to the crisis.

- Compared to conventional loan and Bai' Bithaman Ajil (BBA) financial products for house financing, the diminishing partnership model offers better advantages.

2013 During this year, two conceptual research papers were published. Below is the main finding made:

- It is imperative that Islamic financial institutions follow the ethical principles derived from Shariah, as well as follow ethical standards and guidelines laid down by AAOIFI.

- Islamic finance models for Small and Medium Enterprise (SME) financing could be an alternative to collateral-based debt financing in France.

2014 During this year, only one conceptual research paper was published. Below is the main finding made:

- Unlike Western entrepreneurs, those who follow Islamic entrepreneurship tend to follow ethical-based yardsticks derived from Shariah.

2015 During this year, two conceptual research papers were published. Below is the main finding made:

- In legal documentations of sukuk, it is important to have a governing law clause that enforces the rights of the parties.

- It is imperative for France to adopt Islamic finance as it will attract not only foreign banks, but also provides investment and financing opportunities for Muslims, while paving the way to tap into alternative types of financing, like sukuk, to obtain funding.

2016 During this year, only one conceptual research paper was published. Below is the main finding made:

- 'Fatwa shopping' is common in cross-border Islamic finance transactions, such as cross-border sukuk transactions, where less regulations are imposed.

2017 During this year, two conceptual research papers were published. Below is the main finding made:

- There is a need to improve the Islamic banking regulations in OIC countries.

- A balanced approach in Islamic banking needs to be adopted between institutional, environmental, and societal sustainability to achieve the objectives of Islamic law.

2018 During this year, two conceptual research papers were published. Below is the main finding made:

- A contemporary survey on Islamic banking literature showed a pattern in the body of literature that emphasised on scholars' concerns that led to a paradigm shift in the Islamic financial system.

- A similar study reviewed the Islamic investment literature, which resulted in mixed findings showing that some professionals are not familiar with Islamic investments. 
- Lack of trust is a common issue in developing waqf.

- Islamic finance has the potential to be linked to Sustainable Development Goals (SDGs) and infrastructure financing.

- Organised tawarruq is an acceptable practice in the industry today by presenting various classical and contemporary

views on the acceptability of the concept.

- There are challenges in adopting Islamic finance and accounting standards.

- Istisna' sukuk-based monetary policy is proposed for a faster economic development.

- A new model for the Islamic sovereign wealth fund based on four key pillars was proposed.

2020 During this year, ten conceptual research papers were published. Below are the main findings made:

- An Islamic monetary policy based on qard-al-hasan $(\mathrm{QH})$ was proposed.

- Islamic fintech might disrupt the role played by Islamic financial institutions.

- The financial statements and reports by the Shariah Supervisory Boards found in the annual reports of takaful operators in Bahrain were in line with the practice of segregating both funds.

- The challenges faced in the development of Islamic finance in Balkan countries, with special focus on Bosnia and Herzegovina were identified.

- By using Bahrain as a case study, it was found that takaful operators in general would choose either a hybrid wakalah-mudharabah model or a wakalah model based on how they wish to manage or invest the participant's family or general fund.

- To create judicial support required for Islamic finance services industry, a reform-oriented interpretative approach was suggested.

- There is a number nexus between Islamic finance growth and Islamic real estate finance.

- The differences between bitcoin from the conventional and Shariah perspectives were highlighted.

- A new model for Islamic credit card based on the Musharakah Mutanaqisah (diminishing partnership) concept is proposed.

Source: Author Adopted

TABLE 8. Summary of the Main Findings of Professor M. Kabir Hassan's Empirical Research Papers on Islamic Finance

\begin{tabular}{|c|c|}
\hline Year & Empirical \\
\hline 1998 & $\begin{array}{l}\text { During this year, only one empirical research paper was published. Below is the main finding made: } \\
\text { - The velocity of money and its variance are lower for the non-interest banking system compared with the interest- } \\
\text { based banking system. }\end{array}$ \\
\hline 2003 & $\begin{array}{l}\text { During this year, two empirical research papers published. Below are the main findings made: } \\
\text { - The average cost and profit efficiencies under the parametric DEA techniques were } 55 \% \text { and } 50 \% \text {, respectively in } \\
\text { Sudanese banking system. } \\
\text { - The dividend signalling hypothesis was able to explain the phenomenon of asset concentration in short- and medium- } \\
\text { term investments in the Islamic interest-free banking system, where it was found that dividends in Islamic banks are } \\
\text { stable. }\end{array}$ \\
\hline
\end{tabular}

2005 During this year, only one empirical research paper published. Below is the main finding made:

- There are challenges facing the implementation of Basel II and the regulatory framework required for Islamic banks.

2006 During this year, two empirical research papers published. Below are the main findings made:

- On average, the Islamic banking industry has been relatively less efficient compared to their conventional counterparts in other parts of the world.

- Bank Islam Malaysia Bhd was more liquid, as well as less risky compared with other Islamic banks.

2007 During this year, two empirical research papers published. Below are the main findings made:

- A sample of 100 Islamic bank customers were used to derive the behaviours of customers.

- Zakat is not part of the poverty alleviating instruments considered by the government of Bangladesh, the International Monetary Fund, and the World Bank.

2008 During this year, only one empirical research paper published. Below is the main finding made:

- There are no convincing performance differences between Islamic and non-Islamic indexes for the duration of the study period using evidence from FTSE Islamic indices.

2009 During this year, only one empirical research paper published. Below is the main finding made

- Alongside religion, other factors, such as depositors' desire to achieve the highest return, convenient financial transaction system, consistency in service with uniformity, and higher cost-benefit implications were substantial to clients of Islamic banks in Bangladesh for choosing their intended services. 
2010 During this year, four empirical research papers published. Below are the main findings made:

- There was a significantly positive association between the ethical identity index and market value of the banks.

- Islamic funds had underperformed compared with conventional funds during a financial crisis period in Saudi Arabia.

- There was no difference between Islamic and non-Islamic indexes, and that the Dow Jones Islamic indexes outperformed their conventional counterparts from 1996 to 2000, but had underperformed them from 2001 to 2005.

- There was no convincing performance difference between Islamic and non-Islamic Malaysian unit trust funds.

2011 During this year, two empirical research papers were published. Below are the main findings made:

- Corporate Social Responsibility (CSR) disclosure by Islamic banks varied significantly across the sample.

- Both foreign full-fledged Islamic banks and conventional banks with Islamic bank subsidiaries exhibited negative productivity change, which was attributed to the effects of negative rate of technical change and scale change.

2012 During this year, three empirical research papers were published. Below are the main findings made:

- Islamic funds are highly efficient and that they outperform their international counterparts.

- Most Islamic banks would manage profit distributions, which were directly related to religiosity, financial development, asset composition, and the existence of discretionary reserves.

- Shariah screening process did not have an adverse impact on the absolute or the risk-adjusted performance of Islamic equity mutual funds in Saudi Arabia.

2013 During this year, six empirical research papers were published. Below are the main findings made:

- Two layers of CSR involvement can be found in Islamic banks. The upper layer assures the commitment towards Allah (SWT) by operating under Islamic Shariah. The bottom layer ensures the commitment towards customers, employees, and the society.

- Foreign Islamic banks, on average, were found to follow aggressive financing in host countries and enjoy higher net profit margin.

- Neither Shariah nor the sustainability screening process have adverse impacts on the performance and systematic risk of the investment portfolios compared to their unrestricted conventional counterparts.

- Financial compliance might be rewarding for Shariah-abiding investors, who are interested in the US REIT sector.

- The market reacted negatively towards the announcements of Sukuk before and during the 2007 global financial crisis.

- The forward rate has extremely weak predictive power to forecast the spot profit rate in the long-term profit rate of Malaysian sukuk.

2014 During this year, five empirical research papers were published. Below are the main findings made:

- Both conventional and Islamic banks have negative short-term gaps and positive long-term gaps in OIC countries.

- Capital requirements have a significant impact on the deposit and lending behaviours of 52 Islamic banks (IBs) and 186 conventional banks (CBs) in the sample.

- There was an inverse relationship between profit distribution management and loan loss provisions.

- A country's gross domestic product size was positively related to profitability of microfinance institutions in Muslim countries.

- Ethical identity was not properly understood by the banks in Malaysia.

- Interest rates, currency index, and the FTSE Bursa Malaysia Composite Index posed greater influence on Islamic price index when compared with industrial production, consumer price index, money supply, and investor sentiment indices.

2015 During this year, two empirical research papers were published. Below are the main findings made:

- Islamic banks may exhibit lower signs of earning management, as the Shariah Supervisory Boards in Islamic banks may work as an additional tier in the governance system.

- There was a negative relationship between Saudi Islamic firms and average stock returns in Saudi Arabia.

2016 During this year, seven empirical research papers were published. Below are the main findings made:

- The premiums for publicly listed Islamic banks are $28 \%$ lower than those for publicly listed conventional banks for deposit insurance.

- The governance structure in Islamic banks has allowed them to take higher risks and achieve better performance.

- Participation banks in Turkey suffered more in declined capital adequacy ratio compared to conventional banks.

- There was a benefit from adhering to Shariah law in locally-focused Saudi mutual funds, although there is a cost of this adherence in internationally-focused Saudi mutual funds.

- A positive and significant relationship between Islamic finance and economic growth.

- Using an integrated Multicriteria Decision Making (MCDM) approach, it was found that variables related to both country origin and cost structure have a prominent impact on efficiency of Islamic banks.

- There was a negative relationship between return and volatility, which was valid for most exchange traded funds (ETF) types in Borsa, Istanbul. 
2017 During this year, six empirical research papers were published. Below are the main findings made:

- A new Islamic compliant measure for corporate liquidity was proposed.

- On average, 35\%, 79\%, and 88\% of the selected firms in Bangladesh were Shariah compliant based on debt, liquidity, and interest screens, respectively.

- Islamic banks underperformed their conventional counterparts in more democratic political systems, but outperformed them in hybrid and Shariah-based legal systems.

- Controlling for skewness risks by using an unconditional coskewness measure can improve asset pricing tests by expanding the mean-variance frontier specification.

- The fund manager is more risk averse than the investor for a higher invested capital and weaker expected net profit, the optimal negotiated profit-sharing ratio will be higher.

- Cost efficiency was higher than profit efficiency for the sampled banks in the OIC countries.

2018 During this year, eight empirical research papers were published. Below are the main findings made:

- Attitude, religious motivation, and awareness were important factors that can affect the intention to use Islamic banking in Spain.

- A large variety of firms have the tendency to issue sukuk.

- The higher the number of members in common across the board, the higher the risk-return profile of Islamic indices.

- Sukuk and conventional investment-grade bonds have a lower reaction of conditional volatility to market shocks and higher persistence.

- Shariah law restrictions impacts on Islamic banking capitalisation.

- Stock classification has an effect on stock price co-movements through increased stock trading correlation among a group of Islamic investors and the commonality in preferences among holders of Islamic stocks.

- Higher quality forms of capital can improve the profitability and efficiency of both systems, although the results were stronger for conventional banks.

- Cash waqf donation can play a positive role in increasing the ability of the selected states to alleviate poverty.

2019 During this year, 19 empirical research papers were published. Below are the main findings made:

- Shariah portfolio has a lower level of risk.

- Government insurer can provide strong incentives for banks to take excessive systematic risks.

- Inefficiency caused by non-optimal use of the most advanced banking technology was much more important than managerial inefficiency.

- The technology gap was found to be higher in Islamic banks and foreign banks than in conventional domestic banks.

- Islamic banks have a better way for managing risks than the conventional banks.

- Value of certification on sukuk offerings by a reputable Shariah advisor and a Shariah committee can be associated with a significantly lower average bond spread, as in information certification by reputable lead arrangers.

- New evidence was provided on the impact of the corporate decision to comply with religious and social norms on asset pricing in emerging markets.

- Interest tax would discourage equity financing and can become a hindrance to the overall well-being of humankind.

- Islamic banks have, on average, higher equity financing costs than conventional banks.

- Conventional banks were more exposed to political risks compared to Islamic banks.

- A significant positive nexus was found between oil terms of trade growth volatility and economic growth.

- Attitude and awareness can directly affect intentions of customers, while image, awareness, Shariah compliance, and individualism can directly affect attitude of them and indirectly affect intention mediated by attitude in United Arab Emirates (UAE)

- Malaysian firms have the highest compliance scores using Islamic business scorecard.

- Waqf-based financing has a significant positive impact on educational development in Malaysia.

- The size of the Shariah Supervisory Board can positively and significantly influence the asset return and insolvency risks of Islamic banks.

- A group of 12 countries where interest-free monetary policy (IFMP) is adopted, the misery index (MI) was lower.

- Apart from the perceived ease of online banking, all conceptualised factors were important determinants of customers' behavioural intention in Islamic banking.

- Profit rates of Islamic banks and the interest rates of conventional banks were correlated in an economic environment. 
cont.

2021 During this year, fifteen empirical research papers were published. Below are the main findings made:

- The underlying Islamic finance principles was a factor that was taken into consideration in securitisation.

- Religious factors can affect the determination of financial inclusion.

- Islamic REITs can achieve higher efficiency levels than that of conventional REITs.

- It is imperative to consider the nature of Islamic banking in formulating any monetary policy instruments to deal with credit supply in the economy.

- It is important to address the requirements of customers in the Islamic banking environment.

- Islamic mutual funds can outperform socially responsible funds.

- Big data tools for Islamic financial analysis are important and it can be used in various ways to achieve efficiency in Islamic finance.

- The dividend pay-out policy of Shariah compliant firms have a higher propensity of total pay-out indicating a higher profitability.

- A bibliometric review of takaful literature showed customer perception as a future research area.

- A model for banking with state contingent contracts on asset and liability side is proposed.

- Capitalisation response to increases in insolvency risk was more pronounced with Islamic banks, but has an approximately five-time smaller effect on risk mitigation compared with conventional banks.

- Islamic and conventional funds in developing countries, with weaker legal settings and higher corruption, have higher fixed and performance fees.

- Better Shariah supervisory board (SSB) governance can increase on-balance sheet liquidity creation, but can decrease off-balance sheet liquidity creation.

- A basic pricing model was proposed for sukuk that captured the common risks.

Source: Author Adopted

\section{HIGHLIGHTS OF PROFESSOR M. KABIR HASSAN'S} CONTRIBUTION TO ISLAMIC FINANCE

Professor M. Kabir Hassan is a distinguished professor and global academic leader of Islamic economics and finance. He has earned a leading place in the global circle of Islamic financial experts, researchers, and scholars. He has contributed to the various causes in Islam and among Muslims by playing a monumental role in the development of Islamic economics and finance in the following areas:

PUBLISHING SIGNIFICANT THEORETICAL AND EMPIRICAL RESEARCH IN ISLAMIC FINANCE JOURNAL ARTICLES, BOOK PUBLICATIONS, AND BOOK CHAPTER PUBLICATIONS

Professor M. Kabir Hassan has published scores of publications and research papers on Islamic banking and finance in top-ranking refereed academic journals. He also has over 300 collaborations and co-authorships related to Islamic finance, including books, research papers, working papers, conference papers, workshops, and seminars. His collaborators include prominent and junior scholars of Islamic finance from more than 30 Muslim and non-Muslim countries. His foremost achievement is to convey the importance of Islamic finance to mainstream academic journals of economics and finance. He is among the very few prolific researchers and authors to have published research on Islamic economics and finance in top-ranking and cited refereed journals of conventional finance.
CONTRIBUTING TOWARDS DEVELOPING ISLAMIC FINANCE AS A SEPARATE FIELD OF ACADEMIC DISCIPLINE AND HELPING DEVELOP ISLAMIC FINANCE CURRICULUM

Professor M. Kabir Hassan realised that Islamic finance must be recognised and taught as a separate discipline. Therefore, he co-edited three pioneering textbooks on the subject of Islamic finance, along with 20 scholarly books and more than 50 book chapters. He has also provided academics and practitioners with books on critical writing, Islamic banking, Islamic economics, Islamic capital markets, Islamic entrepreneurship, and a comprehensive account of empirical research in the field of Islamic banking and finance.

\section{BRIDGING A GAP BETWEEN THE EAST AND THE WEST IN ISLAMIC FINANCE RESEARCH}

Professor M. Kabir Hassan has worked as a bridge between the East and the West in making Islamic finance an acceptable academic discipline. His work has developed Islamic finance into an ever-expanding, viable field by attracting significant interest from secular universities and authors. The rigor and quality of Islamic finance articles are improving and have resulted in this field being deemed acceptable by conventional journals. As a result, Islamic finance has progressed from a faith-driven field to an independent academic discipline. The crossover appeal of Islamic finance will prove to be vitally important in securing its place in the global marketplace of economic ideas and eventually, becoming an integral part of the global finance industry. 
TRAINING THE NEXT GENERATION OF ISLAMIC FINANCE SCHOLARS BY SUPERVISING AND EXAMINING THEIR DISSERTATIONS AND THESES

Professor M. Kabir Hassan's teaching services have greatly enhanced the comprehension and acceptance of Islamic financial ideation at the international level. He never hesitates to undertake a multitude of responsibilities, such as supervising and examining dissertations, conducting workshops, and instructing his students in academic writing. He led the way in promoting the long-term viability of Islamic finance by training the next generation of Islamic scholars. At the University of New Orleans, Professor M. Kabir Hassan has produced $64 \mathrm{PhD}$ graduates, with many currently holding important positions in distinguished national and international organisations. Of these organisations, 30 are related to Islamic finance. This is a crucial contribution to the backbone of Islamic finance. PROMOTING ISLAMIC FINANCE VIA KEYNOTE
ADDRESSES IN MAJOR INTERNATIONAL FORUMS

Professor M. Kabir Hassan is a frequent traveller who has presented at conferences, invited lectures, and workshops as a keynote speaker, guest speaker, and conference chair at more than 400 international events. He has earned 33 best paper awards, as well as delivered more than 50 workshops and seminars on Islamic banking and finance. Through these presentations, speeches, and lectures, he has provided both conceptual and contemporary perspectives on Islamic finance to an extensive global audience. He has been working to highlight the true spirit of Islamic finance and enlighten his audience/participants on the mechanisms and rationality of Islamic finance.

IMPACTING SOCIAL DEVELOPMENT BY CONTRIBUTING TO TWO ORGANISATIONS IN BANGLADESH: THE

CENTRE FOR ZAKAT MANAGEMENT AND ISLAMIC BANK BANGLADESH RDS PROGRAMME

Inspired by Professor M. Kabir Hassan's entrepreneurial works and active participation, the Centre for Zakat Management (CZM) was established in 2008. The aims of this centre include to motivate zakat-eligible Muslims to distribute their assets in a Shariah-compliant manner and to change the standard of living of those in abject poverty by providing education, healthcare services, vocational training, and livelihood assistance to affected households. The CZM initiative has been an incredible success story so far. CZM has served more than 9,000 distressed families around the country and created income-generating business for this segment of ultrapoor people. CZM programmes have expanded primary healthcare into hard-to-reach areas, provided children with nutritious food daily, ensured pre-and post-natal care for mothers, upgraded sanitation, and helped thousands of poor students pursue higher education. Professor M. Kabir Hassan was also the architect of the Islamic Bank Bangladesh Limited's (IBBL) Rural Development Scheme (RDS). Under RDS, branches of Islamic banks are encouraged to invest their deposits in areas where social benefits, not profits, are maximised. While many Islamic scholars were sceptical about the applicability of RDS at its inception, today, it is considered as a great success story. RDS has become a huge institution, with many other Islamic organisations adopting similar schemes. Millions of lives have thus been enlightened thanks to the good works of Professor M. Kabir Hassan, who has been working uncompromisingly behind the scenes to transform the lives of millions.

\section{DEVELOPING REGULATORY FRAMEWORKS FOR OIC COUNTRIES}

Professor M. Kabir Hassan has served as a consultant to various international institutions, such as the World Bank (WB), International Monetary Fund (IMF), Islamic Development Bank (IsDB), African Development Bank, USAID, Federal Reserve Bank of the US, and the Organization of Islamic Cooperation (OIC). He recently used SWOT analysis and in-depth survey data to write a report outlining policy recommendations to help OIC countries develop their Islamic finance infrastructure, increase the transparency of their financial systems, and adhere to Shariah law. He has shown that holding true to the principles of Islamic finance can produce a thriving society. Furthermore, he has provided impactful guidance to regulators linking sustainable banking approaches, Islamic banking models, and various societal and environmental issues.

\section{RECOMMENDATIONS AND CONCLUSION}

The findings of this research paper are proof of the exemplary scholarly works conducted by Professor M. Kabir Hassan. He is an inspiration to young and emerging scholars, not only in the field of Islamic finance, but in other fields as well. Professor M. Kabir Hassan's achievements over the past three decades, as presented in this paper, show that perseverance and consistency are required to excel as a scholar. To achieve success, one should also continue to conduct research work and other scholarly work in a consistent manner, without having the mindset of stopping and thinking enough contribution has been made. It is not an easy task to remain motivated for three decades, and this is something that is lacking in many of the young and emerging scholars today. Many lessons that one could learn from the professional life of Professor M. Kabir Hassan and based on this research, we make the following recommendations: 
1. At the time Professor M. Kabir Hassan began his research and publications on Islamic finance, it was an emerging field. As such, it is evident that even in emerging fields, it is possible to produce quality research papers. The quantity can also be increased, while maintaining the quality. Therefore, our recommendation for young and emerging researchers in new fields is to follow this approach to excel in their chosen field.

2. During the time Professor M. Kabir Hassan began his research and publications on Islamic finance, it was hard to find high-impact journals that focus on Islamic finance. Instead of waiting for others to change this, Professor M. Kabir Hassan took the initiative and accepted the challenge of not only creating and establishing separate journals for Islamic finance alone, but also integrating Islamic finance in existing high impact journals. He achieved this feat by actively approaching several journals and convincing them to have special editions for Islamic finance. Eventually, the editors of these journals became exposed to Islamic finance that made them comfortable to accept research papers on Islamic finance, even in the normal issues of their journals. This strategy has not only helped him at an individual level to publish his research papers in high impact journals or become guest editors of such journals, it also paved the way for researchers around the world, who were and are doing research in Islamic finance-related fields to publish their work in high impact journals. Therefore, we recommend young and emerging scholars to adopt a similar strategy in promoting their research work by creating opportunities without waiting for others to change their perception. Collaborative efforts in this regard will create the opportunity for sharing of knowledge, which will eventually make others understand and appreciate one's field, while opening doors for growth.

3. This paper has shown that Professor M. Kabir Hassan is a collaborator in research and publications, and that his network is spread across different countries in the world. In this regard, it was observed that one should never hesitate to join hands with others to expand the knowledge horizon and help each other to disseminate knowledge. As such, we recommend young and emerging scholars to actively participate in networking activities, such as attending conferences and finding partners with whom research collaboration could be made. Through collaboration, novel ideas could be developed into sophisticated and practical concepts that could be used in applied research.

In conclusion, this bibliometric study on Professor M. Kabir Hassan's scholarly works on Islamic finance has shown that he is indeed a role model for other researchers, who are striving to become successful scholars in their respective fields, especially in the arena of Islamic finance. It is imperative to state that even today, Professor M. Kabir is actively working as a prolific scholar, who is continuously striving to produce more quality research papers in the field. He also acts as a lecturer and a mentor for all of his students and young scholars, who aspire to become successful like him.

\section{ACKNOWLEDGEMENT}

The authors would like to acknowledge Professor M. Kabir Hassan for providing his biography and curriculum vitae, with a full list of his publications that have facilitated this research.

\section{REFERENCES}

Abul Mansur M. Masih. 2021. Abul Mansur M. Masih Google Scholar Profile. https://scholar.google.com/ citations?user=B6VMYDYAAAAJ\&hl=en (accessed 18 July 2021)

Ahmad, A. U. F. \& Hassan, M. K. 2007. Regulation and performance of Islamic banking in Bangladesh. Thunderbird International Business Review 49(2): 251277.

Alamad, S. 2017. Financial Innovation and Engineering in Islamic Finance. https://www.springer.com/gp/ book/9783319529462 (accessed 18 July 2021)

Al Rahahleh, N., Ishaq Bhatti, M. \& Najuna Misman, F. 2019. Developments in risk management in Islamic finance: A review. Journal of Risk and Financial Management 12(1):37-59.

Alonso, S., Cabrerizo, F. J., Herrera-Viedma, E. \& Herrera, F. 2009. H-index: A review focused on its fields. Journal of Informetrics 3(4): 273-289.

Ding, Y., Rousseau, R. \& Wolfram, D. 2017. Measuring Scholarly Impact. Cham: Springer.

Frederick J. Friend. 2006. Google scholar: Potentially good for users of academic information. Journal of Electronic Publishing 9(1).

Garraty, J. A. 1957. The nature of biography. The Centennial Review of Arts \& Science 1(2): 123-141.

Garfield, E. 1955. Citation indexes for science: A new dimension in documentation through association of ideas. Science 122(3159): 108-111.

Hulme, E. W. 1923. Statistical Bibliography in Relation to the Growth of Modern Civilization. London: Butler \& Tanner.

Hota, P. K., Subramanian, B. \& Narayanamurthy, G. 2019. Mapping the intellectual structure of social entrepreneurship research: A citation/co-citation analysis. Journal of Business Ethics 166: 89-114.

Ileto, R. C. 2014. Nation and empire in the intellectual biographies of Southeast Asian Scholars. Asian Studies 59(3.4): 9-17.

Islamic Research and Training Institute. 2021. List of Previous Laureates of the Islamic Development Bank (IsDB) Prize in Islamic Economics \& Islamic Banking and Finance. https://irti.org/awards/

Karisiddappa, C. R., Maheshwarappa, B. S. \&Shirol, M. V. 
1990. Authorship pattern and collaborative research in psychology. IASLIC Bulletin 35(2): 73-78.

Kessler, M. M. 1963. Bibliographic coupling between scientific articles. American Documentation 14(1): 1025.

Khalid, M. \& Ur-Rehman, S. 2009. Contributions of Dr. Anis Khurshid to library literature: A bibliometric study. Pakistan Journal of Library and Information Science 10: 43-56.

Lone, F. A. \& Ahmad, S. 2017. Islamic finance: more expectations and less disappointment. Investment Management and Financial Innovations 14(1): 134-141.

Mohamed Ariff, S. M. 2021. Mohamed Ariff Google Scholar profile. https://scholar.google.com/citations?user= 4kH5j9UAAAAJ\&hl=en

Mohammad Kabir, H. 2021. Mohammad Kabir Hassan Google Scholar Profile. https://scholar.google.com/ citations?user $=\mathrm{gKc} 8 \mathrm{ZJMAAAAJ} \& \mathrm{hl}=\mathrm{en}$

Monzer Kahf. 2021. Monzer Kahf Google Scholar Profile. https://scholar.google.com/citations?user=d_ bAE4gAAAAJ\&hl =en

Muhammad Umar, C. 2021. Muhammad Umar Chapra Google Scholar Profile. https://scholar.google.com/citations? user=TycybGwAAAAJ\&hl=en

Persson, O., Danell, R. \& Schneider, J. W. 2009. How to use Bibexcel for various types of bibliometric analysis. In Celebrating Scholarly Communication Studies: A Festschrift for Olle Persson at his 60th Birthday edited by Åström, F., ; Danell, R., Larsen, B. \& Schneider, J. Belgium: International Society for Scientometrics and Informetrics.

Samuelson, P. A. 2007. Reflections on how biographies of individual scholars can relate to a science's biography. In Inside the Economist's Mind: Conversations with Eminent Economists edited by Samuelson, P.A. \& Barnett, W.A. USA: Blackwell Publishing Limited.
Sin, T. W. 1999. Khoo Kay Kim, Professor of Malaysian history: A bibliometric study. Malaysian Journal of Library \& Information Science 4(2): 47-57.

Soong, T. 2019. UNO professor earns high honors for work in international finance. https://www.nola.com/ archive/ article_6f541426-482a-5d95-bde2-88c8782ad57e.html

Svensson, G. 2010. SSCI and its impact factors: A "prisoner"s dilemma'? European Journal of Marketing 44(1-2): 23-33.

Van Eck, N. J. \& Waltman, L. 2010. Software survey: VOSviewer, a computer program for bibliometric mapping. Scientometrics 84(2): 523-538.

Weinberg, B. H. 1974. Bibliographic coupling: A review. Information Storage and Retrieval 10(5-6): 189-196.

Mohammad Mushfiqul Haque Mukit

Jahangirnagar University

Kalabagan Rd, Savar Union 1342

BANGLADESH.

E-mail: mushfiq.mukit@gmail.com

Aishath Muneeza*

International Centre for Education in Islamic Finance (INCEIF)

Lorong Universiti A, 59100, Kuala Lumpur

MALAYSIA.

E-mail: muneeza.aishath@gmail.com

Andrea Paltrinieri

Università Cattolica del Sacro Cuore

Largo A. Gemelli 1, 20123 Milano

ITALY.

E-mail: andrea.paltrinieri@uniud.it

* Corresponding author 